\title{
THE COMMON INTENTION OF THE PARTIES AND THE PAYMENT OF ANNUITIES UNDER THE NUMBERED TREATIES: WHO ASSUMED THE RISK OF INFLATION?
}

\author{
ROBERT MEtCs*
}

The article examines a key term in the so-called Numbered Treaties between the Crown and the Indians of the northwest: the provisions for "annuities" or annual payments in perpetuity by the Crown to the Indian signatories. The author observes that the Crown, in the performance of this obligation, has adhered consistently to the monetary law principle known as nominalism, thus asserting that the common intention of the parties to these treaties was for the First Nations signatories to assume the entire risk of any future loss in value or purchasing power attached to the nominal sums provided. It is argued, however, that the stability of the annuity in terms of purchasing power (with a consequent placement of the risk of any decline in the buying power of the dollar on the Crown) must, if not found explicitly within the terms of the treaties as the expressed intent of the parties, be implied as a reflection of their unexpressed intent. Any interpretation that entails the risk of inflation being assumed by the First Nations signatories must therefore be based entirely on factors other than the common intention of the parties to the Numbered Treaties.
Cet article examine un terme clé dans les soi-disant traités numérotés entre la Couronne et les Indiens du nord-ouest : les dispositions relatives aux «versements périodiques» ou paiements annuels à perpétuité par la Couronne aux Indiens signataires. L'auteur fait remarquer que la Couronne, en respectant cette obligation, s'est constamment conformée au principe de la théorie de la souveraineté nationale en matière monétaire, appelé nominalisme, supposant ainsi que l'intention commune des parties à ces traités consistait pour les Premières nations signataires à assumer le risque entier de toute perte de valeur future de pouvoir d'achat lié aux sommes nominales versées. On peut cependant faire valoir que la stabilité des versements en termes de pouvoir d'achat (avec le risque conséquent du déclin du pouvoir d'achat du dollar sur la Couronne) s'il n'existe pas explicitement dans les conditions des traités comme intention expresse des parties, doit impliquer une réflexion de leur intention non exprimée. Toute interprétation englobant le risque d'inflation assumé par les Première nations signataires doit par conséquent reposer entièrement sur les facteurs autres que l'intention commune des parties aux traités numérotés.

\section{TABLE OF CONTENTS}

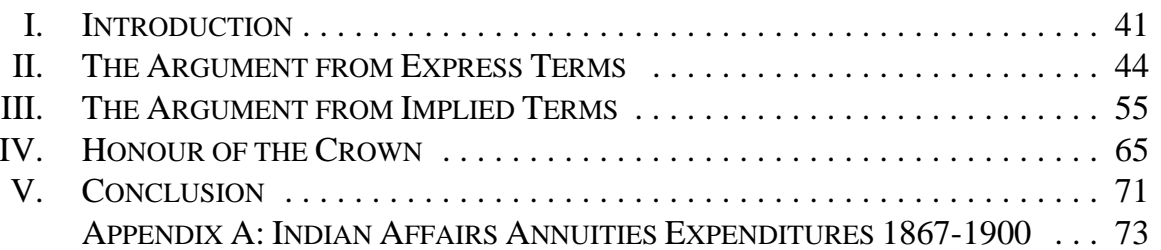

\section{INTRODUCTION}

As preparations were made in the Spring of 1870 to send a military expedition to the new Province of Manitoba to establish effective Canadian sovereignty, arrangements were made with the Indians between Lake Superior and Fort Garry to permit the passage of troops through their territory. These discussions led eventually to the making of Treaties No. 1 and

B.A. (Toronto), M.A. (Carleton) is a partner in the Havlik Metcs Consulting Group (HMCG) which provides negotiation, economic development, claims preparation, and litigation support services to numerous First Nations and Tribal Councils across Western Canada. The author would like to extend special thanks to Tim Watson of HMCG for his helpful comments and assistance in researching various historical aspects of this article. 
No. 2 in 1871, the first of the so-called Numbered Treaties between the new Dominion Government and the Indians of the Northwest. Treaties No. 3 through 7 were negotiated between 1871 and 1877, by which time the only lands not under formal treaty lay far to the north where, it was felt, settlement would be slow to penetrate. The promotion of natural resource development was the primary impetus behind the remaining Numbered Treaties, beginning with Treaty No. 8 (1899-1900) and through Treaties No. 9 (1905-1906), No. 10 (1906), and No. 11 (1921). ${ }^{1}$

A key aspect of these treaties is the provision for "annuities," annual payments in perpetuity by the Crown to the Indian signatories. Treaties No. 1 and 2 provided originally for the payment of $\$ 3$ per annum ${ }^{2}$ to each Indian, "such payment to be made in such articles as the Indians shall require of blankets, clothing, prints (assorted colours), twine or traps, at the current cost price in Montreal, or otherwise, if Her Majesty shall deem the same desirable in the interests of Her Indian people, in cash.”3 This amount was raised in 1875 to \$5 per annum to each Indian and $\$ 25$ to each Chief. Treaties No. 3, 4, 5, 6, 7, 8, 10, and 11 provide for the payment of \$5 per annum to each Indian, \$25 per annum to each Chief of a Band, and $\$ 15$ per annum to a specified maximum number of Band Councillors. ${ }^{4}$ Treaty No. 9 provides for a payment of \$4 per annum to each Indian, to be paid by the Province of Ontario, with various legal issues and agreements between the two levels of government being the explanation for the difference from previous and subsequent Numbered Treaties. ${ }^{5}$

By its continued payment of \$4, \$5, \$15, and \$25 annually, in current legal tender, Canada has engaged in a strict application of the monetary law principle known as nominalism to the annuity provisions of the Numbered Treaties, whereby the obligation of the Crown is taken to be that of rendering annually to the Indians the nominal amount of $\$ 4, \$ 5, \$ 15$, or $\$ 25$ stated in the treaty in such money as the law provides as amounting to $\$ 4, \$ 5, \$ 15$, or $\$ 25$ at the time of payment. ${ }^{6}$ By necessary implication, the First Nations parties to the Numbered

See online: Indian and Northern Affairs Canada (INAC) <http://www.ainc-inac.gc.ca/pr/trts/hti/site/ trindex_e.html>.

2 All dollar amounts in this article are in Canadian currency.

3 Treaties 1 and 2, Between Her Majesty the Queen and the Chippewa and Cree Indians of Manitoba and County, Adjacent with Adhesions, 3 August 1871, online: INAC <http://www.ainc-inac.gc. ca/pr/trts/trty1-2_e.html> [Treaties 1 \& 2].

4 See e.g. Treaty No. 8, 21 June 1899, online: INAC <http://www.ainc-inac.gc.ca/pr/trts/trty8_e.html>: Her Majesty also agrees that next year, and annually afterwards for ever, She will cause to be paid to the said Indians in cash, at suitable places and dates, of which the said Indians shall be duly notified, to each Chief twenty-five dollars, each Headman, not to exceed four to a large Band and two to a small Band, fifteen dollars, and to every other Indian, of whatever age, five dollars, the same, unless there be some exceptional reason, to be paid only to heads of families for those belonging thereto.

For general information on circumstances surrounding the negotiation of Treaty No. 9, see James Morrison, Treaty Research Report: Treaty Nine (1905-06): The James Bay Treaty (Ottawa: Treaties and Historical Research Centre, 1986); E. Brian Titley, A Narrow Vision: Duncan Campbell Scott and the Administration of Indian Affairs in Canada (Vancouver: University of British Columbia Press, 1986) at 60-74. See also Ottawa, National Archives of Canada (RG 10, vol. 3033, file 235, 225, pt. 1). The essential nature of nominalism is described by F.A. Mann, The Legal Aspect of Money, 5th ed. (Oxford: Clarendon Press, 1992) at 90-91 [footnotes omitted, emphasis in original]:

The extent of monetary obligations cannot be determined otherwise than by the adoption of nominalism. The nominalistic principle means that a monetary obligation involves the payment of so many chattels, being legal tender at the time of payment, as, if added together according to the nominal value indicated thereon, produce a sum equal to the amount of the debt. In other 
Treaties have been taken by Canada to have assumed the entire risk of any loss in value attached to the nominal sums provided, in terms of purchasing power or otherwise, even to the point where, as at present, such value may amount to a mere small fraction of the value that inhered in these nominal sums at the time of treaty. ${ }^{7}$

The Supreme Court of Canada, however, has emphasized that the bottom line or "goal of treaty interpretation is to choose from among the various possible interpretations of common intention the one which best reconciles the interests of both parties at the time the treaty was signed." ${ }^{8}$ It is the purpose of this article to suggest that nominalism cannot apply to the annuity provisions of the Numbered Treaties unless it can be shown by Canada to be applicable under this standard.

The primary interpretive problem at issue can be stated as follows: do the facts and circumstances surrounding the making of the various Numbered Treaties support the conclusion that, "from among the various possible interpretations of common intention the one which best reconciles the interests of both parties at the time the treaty was signed"9 is

words, the obligation to pay $£ 10$ is discharged if the creditor receives what at the time of performance are $£ 10$, regardless of both their intrinsic and their functional value. It follows that a monetary obligation has no other value than that which it expresses. Nominalism in this sense is a legal principle, but is empirically derived from a generalization of the normal factual situation. In the vast majority of cases the possibility of changes in monetary value does not enter into the parties' minds, though they may have a definite idea of the exchange value, or purchasing power, of the stipulated amount of money. If they have regard to that possibility, they may safeguard themselves by protective clauses; if they fail to do so, although they anticipate disarrangements of monetary value, they must be taken to have accepted the risks involved. The law does not allow the implication of terms which either do not exist at all or to which the parties failed to give adequate expression. This negative statement, put into positive language, results in the rule that, in the absence of special clauses, parties must be understood to contract (or Parliament must be understood to legislate) with reference to the nominal value of the money concerned as expressed by whatever is legal tender at the time of payment. Nominalism thus finds its justification in the legally relevant intention. Nominalism is a legal principle rather than a mere rule of construction, but is derived from the typical will and idea of the average member of the public or the legislator.

The severe decline in purchasing power of treaty annuity payments has been often noted. See Canada, Royal Commission on Aboriginal Peoples, Report of the Royal Commission on Aboriginal Peoples: Restructuring the Relationship, vol. 2 (Ottawa: Canada Communication Group, 1996) at 77 [footnotes omitted]:

One example of economic rights in the historical treaties is the practice of paying annuities. The Robinson treaties of 1850 and the numbered treaties made after 1870 provide for annual annuities to be paid to each member of a treaty nation. Today, many treaty nation members travel great distances to collect their treaty annuity on treaty day because of the symbolic value of meeting with the Crown's representatives to renew the treaty and affirm the continuing nature of the treaty relationship.

With the passage of time, the value of these annuities, typically $\$ 4$ or $\$ 5$ per year, has been severely eroded. The dollar amount specified in the original treaty is still distributed annually. The annuities established by the Robinson treaties, for example, represented between one-half and onethird of the annual wage of an unskilled labourer.

The lack of any adjustment for inflation is noted briefly by J.R. Miller, Lethal Legacy: Current Native Controversies in Canada (Toronto: McClelland \& Stewart, 2004) at 143: “an annuity of five dollars in many of the western treaties is still paid today to every First Nations man, woman, and child covered by a treaty. Legalistically, Ottawa has made no adjustment for 130 years of inflation.” citing R. v. Sioui, [1990] 1 S.C.R. 1025 at 1068-69 [Sioui]. See also R. v. Morris, 2006 SCC 59, [2006] 2 S.C.R. 915. 
the one where the Indian parties accepted, whether directly or by implication, and however great, the entire risk of any loss in value, in terms of purchasing power or otherwise, attached to the nominal sums stated in the annuity provisions?

Stated differently, do the facts and circumstances that surrounded the making of the various Numbered Treaties support the conclusion that the common intention that best reconciled the interests of the parties at the time of treaty was one where the Indian parties accepted the entire risk that Canada could discharge its obligations under the annuity provisions in greatly depreciated currency, the encouragement or prevention of which possibility Canada held largely within its complete discretion?

The answer, it is suggested, must be no. The stability of the annuity in terms of purchasing power (and consequent placement of the risk of any decline in the buying power of the dollar on the Crown) must, if not found explicitly within the terms of the treaties as the expressed intent of the parties, be implied as a reflection of their unexpressed intent. Any interpretation that entails this risk of inflation being assumed by the First Nations signatories must therefore be based entirely on factors other than the common intention of the parties to the Numbered Treaties.

It is therefore suggested that the obligation of Canada under the annuity provisions of the Numbered Treaties must be to deliver annually a nominal amount in legal tender having a value, in terms of purchasing power, equivalent to that possessed by $\$ 4, \$ 5, \$ 15$, or $\$ 25$ at the time the treaties were entered into by the Indian signatories.

\section{THE ARGUMENT FROM EXPRESS TERMS}

In its most basic form, the annuity provisions of the Numbered Treaties constitute a monetary obligation for Canada and an annual title to money for the Indians. As specified in the treaties, the obligation is performed by the annual delivery by Canada to the Indians of cash money, currency notes, or coins. ${ }^{10}$

Canada has interpreted this obligation consistently as being the annual delivery of the nominal sum stated in the treaties in whatever constituted legal tender at the time of payment. Thus, the delivery of legal tender currency totaling $\$ 4, \$ 5, \$ 15$, or $\$ 25$ in any year subsequent to treaty performed the same function, vis-à-vis the performance of the obligation, as the $\$ 4, \$ 5, \$ 15$, or $\$ 25$ paid to the Indians at the time of treaty. So long as the same nominal amount in current dollars was (or is) delivered annually $(4,5,15$, or 25$)$, the obligation is perceived by Canada as fulfilled. The entire risk, in years subsequent to treaty, of any loss in purchasing power held by the nominal amount of dollars delivered is thus placed entirely on the First Nations signatories. The necessary implication of this position has been, and remains, that the obligation assumed by Canada under the annuity provisions of the Numbered Treaties contains or implies nothing about the actual purchasing power or command over goods and services to be held or possessed by the currency notes or coins delivered annually to the Indians.

10 See Treaties 1 \& 2, supra note 3. With respect to Treaties No. 1 and 2, Canada has long deemed it "desirable in the interests of Her Indian people” to deliver the annuity in cash. 
It is suggested, however, that the interpretation held and acted upon by Canada cannot be "among the various possible interpretations of the common intention the one which best reconciles the interests of both parties at the time the treaty was signed," any claim that the annuity provisions contain or imply nothing about the actual purchasing power of the sums provided cannot be "among the various possible interpretations of the common intention” held by the parties at the time the various treaties were made.

Support for this contention may begin with the statements by John Maynard Keynes that "[a] man does not hold money for its own sake, but for its purchasing power - that is to say, for what it will buy"12 and "[v]aluable articles other than money have a utility in themselves.”13 A currency note, however, when treated as a chattel, is worthless. ${ }^{14}$ It is only when it can be used as a means of exchange to procure goods and services that it acquires value. The value of money thus lies in its economic function, not in its nature. It is a means to an end, not an end in itself. ${ }^{15}$ The dollar is, as the saying goes, what the dollar buys.

The Indian signatories to the Numbered Treaties could not have valued the pieces of paper or metal transferred to them by Canada for their own sake, for their inherent value or utility, but rather for their ability to be exchanged into goods and services. Equally, Canada did not promise to deliver $\$ 4, \$ 5, \$ 15$, or $\$ 25$ annually in currency notes or coins for their utility to the Indians as paper or metal, but for their utility as a means of exchange. The entire value of the annuity provisions to the Indians, as perceived by both parties, lay entirely in the exchange value or purchasing power of the dollars provided. Indeed, as discussed further below, it was apparent to all parties at the time the various treaties were made that the annuities provided to the Indian signatories would be used primarily as a contribution towards the maintenance of a livelihood. Furthermore, in many, if not most cases, it was

$11 \quad$ Marshall, supra note 8 at para. 78, citing Sioui, supra note 8 at 1068-69.

12 A Treatise On Money: The Collected Writings of John Maynard Keynes, The Pure Theory of Money, vol. 5 (London: Macmillan, 1971) at 47 [Keynes, Treatise on Money].

13 A Tract on Monetary Reforms: The Collected Writings of John Maynard Keynes, vol. 4 (London: Macmillan, 1971) at 61 [Keynes, Tract on Monetary Reform]. Keynes also observed at 61: "money as such has no utility except what is derived from its exchange value, that is to say from the utility of the things which it can buy."

14 See Karl Helfferich, Money, trans. by Louis Infield, ed. by T.E. Gregory, vol. 1 (New York: Adelphi, 1927) at 78:

Originally certain economic commodities could also fulfil the, for them, subsidiary functions of money. Metallic coins can at any moment, by being melted down and recast, be converted into articles of ordinary utility, and their value is seen to have been, at first wholly, and later in part, dependent upon the possibility of such conversion. Paper currency, however, is utilisable only as money. As a commodity it is worthless. It is the pure embodiment of monetary functions.

Ibid. at 1-2 (the distinction between money and economic goods in general is emphasized):

This characteristic difference is, quite generally speaking, to be found in the fact that other economic objects ("goods") serve the purpose of direct consumption or of continued use by individual economic units, whereas money acts as a facilitating medium for the exchange of these goods, i.e. money facilitates the transfer of goods from one economic unit to another whilst it does not, so long as it retains its function of money, enter into consumption or continued use by any economic unit. Money is not taken for its own sake; the recipient does not take it for consumption or for prolonged use, but in order, sooner or later, to part with it again, either as a transfer of purchasing power or in return for other economic objects or services.... Considered economically, all those objects of exchange which, in contradistinction to money, we call "goods," are intended for consumption by individual economic units, whereas money fulfils its purpose by passing from hand to hand, finding nowhere a permanent resting-place. 
recognized by all parties that the annuities would be utilized primarily for the purchase of hunting, fishing, and trapping supplies in support of traditional livelihoods.

Put differently, the Indians and Canada did not view or treat the pieces of paper and/or metal used in the discharge of the annuity provisions of the Numbered Treaties as mere pieces of paper or metal but as money, their value as such being viewed by both parties as entirely independent of their direct utility as objects to the Indians (which was nonexistent). The utility to the Indian signatories of the currency notes and/or coins provided lay entirely in the purchasing power they held, their ability to be exchanged into things of direct and immediate use to them, such as, hunting, fishing, and trapping supplies.

The following may therefore be suggested:

(1) The common intention of the parties vis-à-vis the annuity provisions of the Numbered Treaties was not to provide and to receive annually a specific nominal amount of chattels (pieces of paper or metal) called “dollars” (which, in themselves, were recognized by both parties as being of no direct use), but rather the value or purchasing power held by the paper or metal, their ability to be exchanged into objects of direct use to the Indian signatories. The common intention of the parties was, in short, to provide and to receive annually the purchasing or buying power held by $\$ 4, \$ 5, \$ 15$, and $\$ 25$;

(2) As the parties could not have but incorporated within the treaties the value or purchasing power of money that existed at the time the treaty was made to define the extent of their rights and obligations, the common intention of the parties was to provide and to receive annually the purchasing power held by $\$ 4, \$ 5, \$ 15$, and $\$ 25$ as at the time of treaty. ${ }^{16}$ It is relative to the amount of goods and services that the annuity could purchase at that time that the obligation of Canada was viewed and measured by both parties, and it is this value that both parties must have then perceived would be delivered annually "as long as the sun shines and the earth remains." ${ }^{17}$ Indeed, it cannot be doubted that Canada was prepared to offer annually the purchasing power held by $\$ 4, \$ 5, \$ 15$, or $\$ 25$ at the time the treaties were signed, as there is no evidence that either of the parties contemplated seriously the subsequent possibility of a severe and sustained inflation or devaluation in the buying power of the dollar (a matter discussed further below). In consequence, the

16 See Randy E. Barnett, “The Sound of Silence: Default Rules and Contractual Consent” (1992) 78 Va.

L. Rev. 821 at 879 [footnotes omitted]:

Contracts ... can be understood as the enterprise of projecting into the future an imagined "world."

As Steven Burton and Eric Anderson have explained: “Two persons can cooperate by jointly imagining a possible world and, by entering an agreement with a promise on at least one side, committing themselves to each other to bring that world into being by their actions." Of most relevance here is that this projected "world of contract" is usually the same as the present world of the parties in all respects except for the changes explicitly identified by the agreement. The parties silently assume that which "is" will continue to exist. Significantly, much of what they assume is true of the present is only a tacit or subconscious assumption. In other words, contracting parties are often silent - even to themselves - about what they in fact believe.

17 Charles Mair, Through the Mackenzie Basin: An Account of the Signing of Treaty No. 8 and the Scrip Commission, 1899 (Edmonton, University of Alberta Press, 1999) at 63. 
parties came to terms with an explicit or implicit assumption of currency stability, which must imply that Canada was prepared to provide, in perpetuity, the buying power of the dollar current at the time of treaty. ${ }^{18}$ The Crown thus could not have had in any subsequent year, and cannot have now, any objection in principle to providing such value.

At its core, the annuity thus provides for the exercise of a specific level of purchasing power, established at the time of treaty, an obligation that can be fulfilled only via the annual delivery of an equivalent nominal amount of currency to the Indians. The situation is analogous to general comments made by Keynes on the purchasing power of money:

A man does not hold money for its own sake, but for its purchasing power - that is to say, for what it will buy. Therefore his demand is not for units of money as such, but for units of purchasing power. Since, however, there is no means of holding general purchasing power except in the form of money, his demand for purchasing power translates itself into a demand for an equivalent quantity of money. ${ }^{19}$

The argument may be further clarified by noting the critical distinction between the "dollar" as the unit of account or recognized measure of value and the "dollar" as currency or concrete means of payment.

The unit or money of account is, as explained by Keynes, "that in which debts and prices and general purchasing power are expressed.” ${ }^{20}$ He observes:

Money itself, namely that by delivery of which debt contracts and price contracts are discharged, and in the shape of which a store of general purchasing power is held, derives its character from its relationship to the money of account, since the debts and prices must first have been expressed in terms of the latter. ${ }^{21}$

The unit or money of account is a unit of measurement. The quality that it measures is value. Much as pounds or kilograms measure weight, and miles or kilometers measure distance, the dollar as unit of account or common standard allows for the efficient measurement and comparison of value in the marketplace. ${ }^{22}$ In a money economy, everything

18 The term "inflation" is used here to denote an increase in available currency regarded as causing an artificial rise in prices. More generally, but not inconsistently, the term refers to an increase in prices and fall in the purchasing value of money: The Canadian Oxford Dictionary, s.v. "inflation.”

Supra note 12 at 47 . The concept of purchasing power and the possibility of changes in the purchasing power of money over time were perhaps first noted by Bishop Fleetwood, Chronicon Preciosum: or, an Account of English Gold and Silver Money; The Price of Corn and other Commodities; and of Stipends, Salaries, Wages, Jointures, Portions, Day-labour, etc. in England, for Six Hundred Years last past (London: T. Osborne, 1745) at 48-49. Supra note 12 at 49:

[S]ince Money is of no other Use, than as it is the Thing with which we purchase the Necessaries and Conveniencies of Life, 'tis evident, that if V l. in H. VI. Days, would purchase 5 Quarter of Wheat, 4 Hogsheads of Beer, and 6 Yards of Cloth, he who then had $5 l$. in his Pocket, was full as rich a Man as he who has now XX $l$. if with that XX $l$. he can purchase no more Wheat, Beer or Cloth, than the other.

Keynes, Treatise on Money, ibid. at 3 [emphasis in original].

Ibid.

Many writers have drawn the analogy between money and standards of measurement. Writing in 1517, Nicholas Copernicus stated:

Coinage is imprinted gold or silver, by which the prices of things bought and sold are reckoned.... It is therefore a measure of values. A measure, however, must always preserve a fixed and constant 
has one price, expressed in terms of the unit of account (that is, 1,000 goods would have 1,000 prices), as opposed to a barter economy where prices are expressed in terms of each of the goods available for trade (that is, four goods would yield six market prices; 1,000 goods, 499,500 prices). ${ }^{23}$

In terms of its function as unit of account, the "dollar" is an abstraction. As stated by Arthur Nussbaum:

No more can be said than that “dollar" is the name for a value which, at any definite moment, is understood in the same sense throughout the community, and since goods and services are evaluated in terms of the dollar, that unit is a measure or standard of value. ${ }^{24}$

Thus, the "dollar" as unit of account is an abstract standard of value, in terms of which the value of goods and services in an economy are measured (instead of relative to each other as would be required in the absence of such a standard). The unit of account measures also the value of monetary obligations. By contrast, actual currency, bills or coins denominated in, or bearing a specific relation to, the unit of account, are concrete means by which the value expressed by the unit of account can be held and exercised as a means of payment or medium of exchange.

The importance of this distinction for purposes of this analysis arises from the fact that, as noted previously, the value of the dollar at any one time is equivalent to its purchasing power, the amount of goods and services it can be exchanged for. At the time the Numbered Treaties were being negotiated, the dollar for both parties thus carried a recognized value in terms of buying power. The significance of money to any individual depends primarily on two things: (1) how many dollars of income he gets (the nominal amount of dollars); and (2) what each of those dollars will buy (the purchasing power held by the dollar). His or her real income or total buying power is the product of these two factors, the buying power of the dollar multiplied by the number of dollars in his income. The situation was no different for the Indian signatories at the time of the treaties, the value of the annuity in real terms being equivalent to the nominal sum of dollars provided multiplied by the buying power of the dollar.

At the time each treaty was entered into, the real and nominal incomes related to the annuities were equivalent. The dollars in concrete currency delivered to the Indians held the full value of the promised purchasing power expressed by the dollar as unit of account, reflecting the fact that the distinction between units of account and actual means of exchange or payment is immaterial in agreements involving the immediate performance of obligations. It is only in subsequent years that the distinction began to take on crucial significance, as the

standard. Otherwise, public order is necessarily disturbed, with buyers and sellers being cheated in many ways, just as if the yard, bushel, or pound did not maintain an invariable magnitude. Pawel Czartoryski, ed., Nicholas Copernicus Minor Works, trans. by Edward Rosen (Cracow, Poland: Polish Scientific Publishers, 1985) at 176-77 [footnotes omitted].

23 Barter trades can, of course, still be made within a monetary framework (i.e. $\$ 10$ worth of grain can be traded for $\$ 10$ worth of blankets). The dollar, in this case, nevertheless remains the unit of account or common measure of value. 
nominal amount of dollars issued to the Indians held an increasingly reduced level of purchasing power as related to the equivalent nominal amount issued at the time of treaty. ${ }^{25}$ The value, in terms of purchasing power, expressed by the dollar as unit of account at the time of treaty was not, in subsequent years, provided to the Indians by the delivery to them of a dollar in actual currency. Stated differently, the actual value or purchasing power held and exercised annually by the Indians in later years via the currency provided to them was not equivalent to the value of the obligation as expressed and agreed by both parties at the time of treaty.

Thus, when viewed against the distinction between the dollar as unit of account and the dollar as concrete means of payment, the promise to deliver annually $\$ 4, \$ 5, \$ 15$, and \$25 can mean two distinct things: the promise to deliver chattels (paper or token coins) in which a total of \$4, \$5, \$15, and \$25 as units of account are incorporated; or the promise to deliver the amount in currency having the value or purchasing power of $\$ 4, \$ 5, \$ 15$, and $\$ 25$ at the time of treaty. If, then, as suggested above, the common intention of the parties was to provide for the exercise of a specific level of purchasing power established at the time of treaty and measured in dollars as the unit of account or standard of value, the promise to pay \$4, \$5, \$15, and \$25 annually, in perpetuity, must be taken as the latter of these two possible interpretations: the promise to pay annually a nominal sum in currency holding the equivalent in buying power to that held by $\$ 4, \$ 5, \$ 15$, and $\$ 25$ at the time of treaty. The risk of any decline in the buying power of the dollar from that existing at the time of treaty was thus assumed explicitly by the Crown.

The above conclusion with respect to the common intention of the parties would appear to be open to challenge only to the extent it can be shown that both parties, at the time of treaty, were aware of the possibility of a significant decline in the value or purchasing power of the dollar subsequent to treaty and, further, that the Indians understood and accepted the risk of any such decline. Such a scenario, it is suggested, cannot be supported.

Each of the parties to the Numbered Treaties, it would appear, could have held one of two explicit or implicit/tacit assumptions with respect to the stability of money in terms of purchasing power: (1) the value of money, in terms of purchasing power, would remain stable or even relatively stable as against that in existence at the time of treaty; and (2) the value of money could fluctuate in terms of buying power, in particular that the buying power 1990) at 200 [Ray, Canadian Fur Trade]:

[I]n 1870 a native hunter with a family could equip himself for about $\$ 20-\$ 25$ dollars per year about the equivalent of his family's annuity income. Although the purchasing power of $\$ 25$ of annuity money had risen to $\$ 36$ by 1900 , it dropped sharply thereafter until it was worth only about $\$ 10$ in $1920 \ldots$. With the strong deflation that marked the early years of the depression, it temporarily increased to $\$ 23$ in 1931 before declining once again to $\$ 15$ in 1945 . So, over the years inflation seriously eroded the value of the Indians' annuity income.

Consistent and high inflation rates in the 1960s, 1970s, and 1980s, and lower but still consistent inflation since that time has eroded further the purchasing power of the annuities to their current insignificance as related to that held at the time of treaty. 
of a dollar issued in subsequent years could decrease significantly from that held by a dollar issued at the time of treaty. ${ }^{26}$

If we label Canada as C, the First Nations as FN, assumption (1) above as 1 and assumption (2) above as 2, four possible combinations (A, B, C, and D) are therefore suggested with respect to the assumptions held by the parties at the time the various treaties were made with respect to the stability in the buying power of money:

$\begin{array}{llll}\underline{\mathrm{A}} & \mathrm{C} 1 & \text { FN } & 1 \\ \underline{\mathrm{B}} & \text { C } 1 & \text { FN } & 2 \\ \underline{\mathrm{C}} & \text { C } 2 & \text { FN } & 1 \\ \underline{\mathrm{D}} & \text { C } 2 & \text { FN } & 2\end{array}$

It may be asserted immediately that B and D are not possible on the facts. The historical and cultural context within which the Numbered Treaties were negotiated and signed was that of one party (Canada) with considerable knowledge of, and experience with, money and the dynamics of a non-barter economy, where money is used as a medium of exchange and store of value, and that of the other party (the First Nations) with no or extremely limited practical knowledge of, and experience with, money and who still, primarily if not in many cases almost entirely, maintained a livelihood by participation in the traditional credit/barter system linked to the fur trade. ${ }^{27}$ Under these circumstances, it is at the very least doubtful that the First Nations parties to the Numbered Treaties had any knowledge of inflation, much less understood the possible long-term consequences of such a phenomenon relative to the annuities they were promised. Further, the available historical record discloses little evidence to suggest that Canada discussed the concept of inflation with the First Nations, much less informed them of its potentially pernicious effects on fixed long-term monetary obligations. To the contrary, it may be observed that the various Treaty Commissioners were at great pains to create a presumption of continuity in the minds of the Indians with respect to obligations assumed by the Crown under the treaties. ${ }^{28}$ It cannot be maintained, therefore,

See supra note 16 at 877, citing Lon L. Fuller \& Robert Braucher, Basic Contract Law (St. Paul, Minn.: West, 1964) at 555 [emphasis in original], explains the term "tacit assumption":

Words like "intuition," "assumption," "expectation” and "understanding” all seem to imply a conscious state involving an awareness of alternatives and a deliberate choice among them. It is, however, plain that there is a psychological state which can be described as a "tacit assumption" that does not involve a consciousness of alternatives. The absent-minded professor stepping from his office into the hall as he reads a book "assumes" that the floor of the hall will be there to receive him. His conduct is conditioned and directed by this assumption, even though the possibility that the floor has been removed does not "occur" to him, that is, is not present in his conscious mental processes.

27 Supra note 25, describes the conditions and economy of the First Nations of the northwest during the Numbered Treaty period. Ray notes at 40 that "[b]y drawing cash merchandisers into the north for the first time, annuity payments served as a catalyst for the movement of native people away from the credit/barter system of the pre-Confederation fur trade and towards a new economic order in which buying furs and merchandising were increasingly separated and cash transactions became more commonplace.” See also Charles A. Bishop \& Arthur J. Ray, "Ethnohistoric Research in the Central Subarctic: Some Conceptual and Methodological Problems” (1976) 6:1 The Western Canadian Journal of Anthropology 116.

28 For Treaties No. 1-7, see The Hon. Alexander Morris, The Treaties of Canada with The Indians of Manitoba and the North-West Territories: including The Negotiations on which they were based, and other information relating thereto (Toronto: Belfords, Clarke \& Co., 1880, reprinted Saskatoon: Fifth 
that the First Nations entered into the Numbered Treaties with anything but an implicit/tacit assumption that the value of their annuity, in terms of the goods and services it could be exchanged for, would remain stable for the years subsequent to treaty.

House, 1991). For Treaty No. 8, see supra note 17; René Fumoleau, As Long as This Land Shall Last: A History of Treaty 8 and Treaty 11, 1870-1939 (Calgary: University of Calgary Press, 2004). For Treaty No. 9, see supra note 5. For Treaties No. 1-5, 8, 10, see Arthur J. Ray, Jim Miller \& Frank J. Tough, Bounty and Benevolence: A History of Saskatchewan Treaties (Montreal \& Kingston: McGillQueen’s University Press, 2000) [Ray, Miller \& Tough, Bounty]. For Treaty No. 11, see Fumoleau, above. The following is taken from the Treaty No. 8 negotiations at Lesser Slave Lake, Alberta, in 1899, as recalled by Mair at 56-63:

[Commissioner Laird] Now, I will give you an outline of the terms we offer you. If you agree to take treaty, every one this year gets a present of \$12.00. A family of five, man, wife and three children, will thus get $\$ 60.00$; a family of eight, $\$ 96.00$; and after this year, and for every year afterwards, \$5.00 for each person forever. To such chiefs as you may select, and that the Government approves of, we will give \$25.00 each year, and the counsellors \$15.00 each (at 57). ...

KEENOOSHAYO: Are the terms good forever? As long as the sun shines on us? Because there are orphans we must consider, so that there will be nothing to be thrown up to us by our people afterwards. We want a written treaty, one copy to be given to us, so we shall know what we sign for (at 62).

MR. LAIRD: Treaties last forever, as signed, unless the Indians wish to make a change (at 63).

[Father Lacombe] Your forest and river life will not be changed by the Treaty, and you will have your annuities, as well, year by year, as long as the sun shines and the earth remains (at 63).

With reference to Treaties No. 1 -11 as a whole, see Canada, Royal Commission on Aboriginal Peoples, Looking Forward, Looking Back: Report of the Royal Commission on Aboriginal Peoples, vol. 1 (Ottawa: Canada Communication Group, 1996) at 174-75:

As we have seen from these brief descriptions of the individual treaties, from the perspective of the First Nations there were several basic elements or principles involved in the treaty-making process. In making treaties both parties recognized and affirmed one another's authority to enter into and make binding commitments in treaties. In addition, First Nations would not consider making a treaty unless their way of life was protected and preserved. This meant the continuing use of their lands and natural resources. In most, if not all the treaties, the Crown promised not to interfere with their way of life, including their hunting, fishing, trapping and gathering practices. The Crown asked First Nations to share their lands with settlers, and First Nations did so on the condition that they would retain adequate land and resources to ensure the well-being of their nations. The Indian parties understood they would continue to maintain their traditional governments, their laws and their customs and to co-operate as necessary with the Crown. There was substantive agreement that the treaties established an economic partnership from which both parties would benefit. Compensation was offered in exchange for the agreement of First Nations to share. The principle of fair exchange and mutual benefit was an integral part of treaty making. First Nations were promised compensation in the form of annual payments or annuities, social and economic benefits, and the continued use of their lands and resources.

These principles, which were part and parcel of the treaty negotiations, were agreed upon throughout the oral negotiations for Treaties 1 through 11. They were not always discussed at length, and in many cases the written versions of the treaties are silent on them. In these circumstances, the parties based their negotiations and consent on their own understandings, assumptions and values, as well as on the oral discussions. First Nations were assured orally that their way of life would not change unless they wished it to. They understood that their governing structures and authorities would continue undisturbed by the treaty relationship. They also assumed, and were assured, that the Crown would respect and honour the treaty agreements in perpetuity and that they would not suffer — but only benefit — from making treaties with the Crown. They were not asked, and they did not agree, to adopt non-Aboriginal ways and laws for themselves. They believed and were assured that their freedom and independence would not be interfered with as a result of the treaty. They expected to meet periodically with their treaty partner to make the necessary adjustments and accommodations to maintain the treaty relationship. 
With respect to the remaining possibilities, A and C, the historical facts and circumstances that surrounded the making of the Numbered Treaties would strongly suggest A. That Canada would have negotiated and entered into the Numbered Treaties with the implicit/tacit (if not indeed explicit) assumption that the value of money, in terms of purchasing power, would remain stable or even relatively stable is supported by the widespread belief of British and Western society in the stability and safety of money throughout the 100 year period prior to the outbreak of World War I. ${ }^{29}$ Indeed, during the Numbered Treaty period (the sole exception being Treaty No. 11, signed 1921-22), every major economy in the world was on the gold standard. ${ }^{30}$ Britain had been on a full legal gold standard from 1821 . The Canadian situation is summarized by James Powell:

From 1 August 1854 when the Currency Act was proclaimed, until the outbreak of World War I in 1914, the Province of Canada, and subsequently the Dominion of Canada, was continuously on a gold standard. Under this standard, the value of the Canadian dollar was fixed in terms of gold and was convertible upon demand. It was also valued at par with the U.S. dollar, with a British sovereign valued at Can\$4.8666. ${ }^{31}$

See supra note 13 at 10 [footnotes omitted, emphasis in original]:

[I]t is easy at all times, as a result of the way we use money in daily life ... to look on money as itself the absolute standard of value; and when, besides, the actual events of a hundred years have not disturbed his illusions, the average man regards what has been normal for three generations as a part of the permanent social fabric.

The course of events during the nineteenth century favoured such ideas. During its first quarter, the very high prices of the Napoleonic Wars were followed by a somewhat rapid improvement in the value of money. For the next seventy years, with some contemporary fluctuations, the tendency of prices continued to be downwards, the lowest point being reached in 1896. But while this was the tendency as regards direction, the remarkable feature of this long period was the relative stability of the price level. Approximately the same level of price ruled in or about the years 1826, $1841,1855,1862,1867,1871$, and 1915. Prices were also level in the years 1844, 1881, and 1914. If we call the index number of these latter years 100 , we find that, for the period of close on a century from 1826 to the outbreak of war, the maximum fluctuation in either direction was 30 points, the index number never rising above 130 and never falling below 70 . No wonder that we came to believe in the stability of money contracts over a long period.

See also David Hackett Fischer, The Great Wave: Price Revolutions and the Rhythm of History (New York: Oxford University Press, 1996) at 156-90.

As stated by Barry Eichengreen, a leading authority on the history and functioning of the system. Barry

Eichengreen, ed., The Gold Standard in Theory and History (New York: Methuen, 1985) at 3-4:

The three basic features of a gold standard regime are (i) interconvertibility between domestic money and gold at a fixed official price, (ii) freedom for private citizens to import and export gold, and (iii) a set of rules relating the quantity of money in circulation in a country to that country's gold stock. An international gold standard exists when a number of countries adhere to these principles. With each country willing to convert its domestic currency into a fixed weight of gold and with the price of gold set on world markets subject only to the margins covering shipping and insurance costs, an international gold standard establishes fixed exchange rates between national currencies. Balance-of-payments settlements are effected through international transfers of gold, and balance-of-payments equilibrium is obtained through the impact of gold flows on internal conditions.

The international gold standard is sometimes portrayed as the normal state of affairs prior to World War I. Yet a gold standard regime embodying the basic features listed above prevailed on a global scale only for a third of a century, from 1880 to 1914.

31 James Powell, A History of the Canadian Dollar (Ottawa: Bank of Canada, 2005) at 33. When WWI commenced, Canada, like Britain, went off the gold standard (at 33-34). Canada only returned to the standard on 1 July 1926 (at 40). However, by Order in Council dated 10 April 1933, Canada suspended the redemption of Dominion Notes for gold, thus ending its adherence to the gold standard (at 43). Since that time, the Canadian dollar has either floated against other currencies or been pegged to the U.S. dollar (1962-70) (at 53-84). Treaty No. 11, made in 1921-1922, preceded the brief post-WWI return by 
As stressed by Robert Mundell, currencies under the gold standard system "were just names for particular weights of gold." ${ }^{32}$ During the period that Canada and the First Nations entered into Treaties No. 1-10, government-issued currency notes were redeemable in specie on demand, a dollar then representing a legal claim to a specified quantity of gold. By contrast, a dollar currency note tendered today in fulfillment of the annuity provisions represents no such claim. The former represented a legal claim to a certain commodity with inherent economic value, the latter now merely a legal claim to new notes of the same nominal value. ${ }^{33}$

Barry Eichengreen has emphasized that the success of the gold standard system depended critically upon the unquestioning attachment by governments to credibility, the rejection of any possibility that a nation would allow itself to go permanently off gold or to vary its gold

Canada to the gold standard in 1926.

Robert L. Bartley, “Money: The Century’s Agony” The Wall Street Journal (10 December 1999) A19; Peter L. Bernstein, The Power of Gold: The History of an Obsession (New York: John Wiley \& Sons, 2000) at 243.

33 See Helfferich, supra note 14 at 65, the differing possibilities of a significant decline in the value of paper currency under these two circumstances is noted:

As in the case of coins struck with a content below their nominal value, so with these money tokens the aim was to keep them at their nominal value expressed in terms of the State currency. The most effective means to this end is the promise to redeem on demand these paper tokens at their nominal rate in terms of the other currency - mostly metallic currency of a standard value. This promise of redemption existed in advance in the case of the paper tokens issued by private individuals and banks, which tokens had their origin, not in the State's privilege of creating media of payment, but in the promise to pay given by private individuals and institutions which were well known to be capable of payment. These private fiduciary issues developed into bank-notes in the modern sense of the word. As long as this redeemability is not a dead letter, but an actuality, the value of the paper currency issued by the State, or of the bank-notes issued by private individuals, cannot materially deviate from their nominal value expressed in terms of metallic currency. The value of the paper tokens is thus, indirectly, closely connected with the value of a specified quantity of metal which forms the basis of the existing currency system.

In many cases, however, this support for the maintenance of the value of the paper tokens was destroyed. In place of redemption we frequently find, both in the case of the paper money of the State as well as in the case of bank notes, an inconvertible or "forced issue".... In other words, we find a command by the State that the notes issued by it or by the bank must be accepted at the nominal value assigned to them irrespective of whether they are redeemable or not.

As money is used for payment of past debts as well as for present cash transactions, the "forced issue" of paper currency is inevitably accompanied and/or sustained by legal tender laws. In F.A. Hayek, Denationalisation of Money: An Analysis of the Theory and Practice of Concurrent Currencies (Great Britain: Institute of Economic Affairs, 1976) at 32, Hayek quotes from a paper on legal tender written in 1895 by Lord Farrer [footnotes omitted, emphasis in original]:

Looking to the above cases of the use or abuse of the law of legal tender other than the last [i.e. that of subsidiary coins] we see that they possess one character in common — viz. that the law in all of them enables a debtor to pay and requires a creditor to receive something different from that which their contract contemplated. In fact it is a forced and unnatural construction put upon the dealings of men by arbitrary power.

Hayek goes on to observe (at 32):

[T]ruth is indeed that legal tender is simply a legal device to force people to accept in fulfilment of a contract something they never intended when they made the contract. It becomes thus, in certain circumstances, a factor that intensifies the uncertainty of dealings and consists, as Lord Farrer also remarked in the same context,

"in substituting for the free operation of voluntary contract, and a law which simply enforces the performance of such contracts, an artificial construction of contracts such as would never occur to the parties unless forced upon them by an arbitrary law.” 
parity, and to the co-operation that such credibility warranted. ${ }^{34}$ Preservation of convertibility to gold at fixed rates was the bedrock of economic policy, before which all other considerations had to give way. Peter L. Bernstein notes:

\begin{abstract}
The group of nations that adopted the gold standard developed into a kind of fraternity — an enviable and exclusive group whose members protected one another from the hazards and uncertainties imposed on them by the world beyond their borders. The great economist and historian Joseph Schumpeter described the attraction of the gold standard as a search for national prestige, "a symbol of sound practice and badge of honor and decency," with a value that was independent of purely economic advantages. A contemporary member of the Austrian parliament warned his colleagues about the loss of "esteem" that their nation suffered by being "a scrap-of-paper economy.” A Russian economist asserted that "Membership in worldwide civilization is unthinkable without membership in the worldwide monetary economy.” John Sherman, a prominent member of the U.S. Congress and of presidential cabinets, declared that a currency without redeemability into gold was a "national dishonor., 35
\end{abstract}

\title{
He continues:
}

Once the gold standard was in place, paper notes and bank deposits as well as holdings of foreign exchange were considered as little more than convenient substitutes for the "real thing," assets that enjoyed acceptability purely by virtue of being convertible into gold.

So potent was this image after the Armistice in 1918 that few people dared to suggest — or even notice that the gold standard had been rendered obsolete by the social, economic, and political earthquakes unleashed by the bloody struggle of the First World War. Andrew Boyle, biographer of Montagu Norman, the man who served as Governor of the Bank of England from 1920 to 1944, put it this way: "Anyone rash enough then to have advocated a different course might well have been locked up and certified as insane. No alternative plan was conceivable."36

These facts support the conclusion that the Crown entered into Treaties No. 1-10 under the prevailing assumption that the Canadian dollar would remain fixed in terms of gold and convertible into gold on demand. Under these circumstances, it must follow that Canada held the implicit/tacit (if not indeed, explicit) assumption that the value of the Canadian dollar, in terms of purchasing power, would remain stable or even relatively stable, as related to that in existence at the time these treaties were made. With respect to Treaty No. 11, the return of Canada to the gold standard in 1926 suggests that the latter assumption must apply to this agreement as well.

Finally, with respect to possibility $\mathrm{C}$ above, it is suggested that had Canada nevertheless recognized and considered the possibility that the value or buying power of the dollar could in subsequent years decline significantly relative to that in existence at the time the treaties

34 Barry Eichengreen, Globalizing Capital: A History of the International Monetary System (Princeton, Princeton University Press, 1996) at 32-35.

35 Bernstein, supra note 32 at 240 [footnotes omitted]: he goes on to note that "Britain was the charter member of the club, even its inventor."

$36 \quad$ Ibid. at 241 [footnotes omitted]. 
were made, yet entered into them regardless, it would have acted dishonourably. As observed by Keynes, "[the] most striking consequence [of inflation] is its injustice to those who in good faith have committed their savings to titles to money rather than to things." 37 No less of an injustice exists in the case of contracts to receive fixed sums of money at future dates, a class of agreement under which fall the annuity provisions of the Numbered Treaties. The value or purchasing power held by the nominal amount tendered in fulfillment of the obligation can, in such cases, be far less than the value or purchasing power held by the stated nominal amount at the time of agreement. The expectation of the parties as to value given and received is defeated. Inflation benefits government in particular by reducing the burden of its pre-existing liabilities insofar as they have been fixed in terms of money. Every step of monetary depreciation means a reduction in the real claims against government debt obligations. The Crown and Treaty Commissioners knew that the Indian signatories to the Numbered Treaties could have had no meaningful or practical comprehension as to the possibility of monetary inflation or its potential consequences. With this knowledge, it would have been against the honour of the Crown for Canada to have been aware of the possibility of inflation, and the fact that this would entail a corresponding gain to Canada for every loss endured by the First Nations, yet entered into the treaties without disclosure of these risks to those First Nations. ${ }^{38}$ There is no evidence that any such disclosure was made.

In the result, it is suggested that the common intention of the parties vis-à-vis the annuity provisions of Numbered Treaties was that the Crown undertook to pay annually a nominal sum in currency holding the equivalent in buying power to that held by $\$ 4, \$ 5, \$ 15$, and $\$ 25$ at the time the treaties were made. The risk of any subsequent decline in the buying power of the dollar was thus allocated by the parties to the Crown.

\section{THE ARguMENT FROM IMPLIED TERMS}

The following statement from Binnie J., writing for the majority of the Supreme Court of Canada in Marshall, may be noted:

\footnotetext{
"Generous" rules of interpretation should not be confused with a vague sense of after-the-fact largesse. The special rules [of treaty interpretation] are dictated by the special difficulties of ascertaining what in fact was agreed to. The Indian parties did not, for all practical purposes, have the opportunity to create their own written record of the negotiations. Certain assumptions are therefore made about the Crown's approach to treaty making (honourable) which the Court acts upon in its approach to treaty interpretation (flexible) as to the existence of a treaty (Sioui, supra, at p. 1049), the completeness of any written record (the use, e.g., of context and implied terms to make honourable sense of the treaty arrangement: Simon $v$. The Queen, [1985] 2 S.C.R. 387, and R. v. Sundown, [1999] 1 S.C.R. 393), and the interpretation of treaty terms once found to exist (Badger). The bottom line is the Court's obligation is to "choose from among the various possible interpretations of the common intention [at the time the treaty was made] the one which best reconciles” the Mi'kmaq interests and those of the British Crown (Sioui, per Lamer J., at p. 1069). ${ }^{39}$
}

He then expanded upon the use of implied terms in the interpretation of Indian Treaties: 
The law has long recognized that parties make assumptions when they enter into agreements about certain things that give their arrangements efficacy. Courts will imply a contractual term on the basis of presumed intentions of the parties where it is necessary to assure the efficacy of the contract, e.g., where it meets the "officious bystander test”... If the law is prepared to supply the deficiencies of written contracts prepared by sophisticated parties and their legal advisors in order to produce a sensible result that accords with the intent of both parties, though unexpressed, the law cannot ask less of the honour and dignity of the Crown in its dealings with First Nations. The honour of the Crown was, in fact, specifically invoked by courts in the early 17 th century to ensure that a Crown grant was effective to accomplish its intended purpose. ${ }^{40}$

To apply these principles to the annuity provisions of the Numbered Treaties is to suggest that the stability of the annuity in terms of purchasing power (and the consequent placement of the risk of any subsequent decline in the buying power of the dollar on the Crown) must, if not found explicitly within the terms of the treaty as the expressed intent of the parties, be implied as a reflection of their unexpressed intent.

Contracts or agreements to receive fixed sums of money at future dates depend for their purpose upon the assumption of stable money values. ${ }^{41}$ Their usefulness to the creditor or recipient depends entirely upon such stability. No reasonable or prudent individual would give equivalent current value in return for a perpetual annuity, at a fixed nominal dollar sum, if there was, at the time of agreement, any recognition that the purchasing power of that annuity could, at some time in the future, be eroded significantly. This statement is supported by the evident and widespread use throughout history of protective value clauses in longterm commercial agreements, a practice that continued to be common at the time the Numbered Treaties were entered into. ${ }^{42}$

Ibid. at para. 43 [footnotes omitted]. Justice Binnie went on to note that various cases decided previously by the Supreme Court of Canada "employed the concept of implied rights to support the meaningful exercise of express rights granted to the first nations in circumstances where no such implication might necessarily have been made absent the sui generis nature of the Crown's relationship to aboriginal people” (at para. 44).

$41 \quad$ Supra note 13 at 4 [emphasis in original]: "Of the various purposes which money serves, some essentially depend upon the assumption that its real value is nearly constant over a period of time. The chief of these are those connected, in a wide sense, with contracts for the investment of money ... namely, those which provide for the payment of fixed sums of money over a long period of time.” See also Karl Helfferich, Money, trans. by Louis Infield, ed. by T.E. Gregory, vol. 2 (New York: Adelphi, 1927) at 341: "The function of money as a medium of transfer of wealth from person to person presupposes a confidence in the stability of its purchasing power.”

42 The nature and use of "gold clauses" and protective value clauses in general during the gold standard period are discussed by Nussbaum, supra 24 at 301-306 [footnotes omitted, emphasis in original]:

In a modern monetary system the greatest danger to persons contracting in terms of money lies in the fact that the monetary unit may be severed from gold, and may therefore be subjected to the unpredictable processes of depreciation and appreciation in the markets. Before the appearance of the modern monetary systems, it was debasement or alteration in the tariffing of the coin contracted for that was feared. Hence creditors have never been free from the threat of monetary changes. As far back as the latter part of the middle ages, when monetary economy began to develop, creditors protected themselves against losses from such changes by appropriate contractual provisions.... While the protective clauses of early times were ordinarily articulated in terms of special coins of gold or silver, under a developed monetary system they call for the payment of a definite amount of the basic unit, with the caveat, however, that only gold coins or silver coins of the system or either of them may be used in payments, thus excluding paper money and minor coins.... However, it was the gold clause which had by far the greatest expansion. By this clause the debtor promises to pay a sum of money, gold coin or equivalent. It is found chiefly in long term contracts, such as mortgage deeds, life insurance policies, and loan bonds, particularly 
In Marshall, Binnie J. implied that terms are to be used "to make honourable sense of the treaty arrangement." ${ }^{23}$ As stressed above, the utility to the Indian signatories of the currency provided pursuant to the annuity provisions lay entirely in the purchasing power they held, their ability to be exchanged into things of direct and immediate use to them. A perpetual annuity without consistent or even relatively stable purchasing power would turn a provision that was presented to the Indians in a context of predictability and continuity into the equivalent of what today we would call an unhedged speculation on the continued stability of the Canadian dollar, a gamble that history to that time had all but confirmed would place the benefit of the odds entirely to the side of the Crown. To imply the possibility of such a result into the Numbered Treaties, based upon the presumed intention of the parties, cannot in any way, given the purpose and context of the annuity provisions, be said to "make honourable sense of the treaty arrangement." 44 To paraphrase, therefore, the query posted by the officious bystander referred to by Binnie J. in Marshall: "This talk about the payment of annuities for as long as the sun shines and the rivers flow is all very well, but will the money paid to the Indians in the future be as valuable to them in terms of what it can be exchanged for as is the money you give them today?” The answer would have to be, having regard to the honour of the Crown, "of course."

The above conclusion, it is suggested further, does not exceed what "is possible on the language” nor is it unrealistic. ${ }^{46}$ As observed previously, it cannot be doubted that Canada was prepared to offer annually, and in perpetuity, the purchasing power held by $\$ 4, \$ 5, \$ 15$, or $\$ 25$ at the time the various treaties were made which must imply, absent evidence that either party contemplated the subsequent possibility of a severe and sustained inflation or devaluation in the buying power of the dollar, that Canada was prepared to provide, annually and in perpetuity, the buying power of the dollar current at the time of treaty. Nothing in

of an international character. In times of monetary troubles, however, the gold clause makes an appearance even in bills of exchange and other short term evidence of indebtedness.

There is probably no country in which the gold clause has been more widely used than in the United States.... The insertion of the gold clause in bonds and mortgages was a matter of routine. Memories of the Continentals, the state bank notes, and the greenbacks contributed to this result; but probably the most effective cause was the pre-war silver agitation. In Germany it was doubtless the bimetallistic endeavors of powerful agrarian parties which before the World War caused the gold clause to pervade the whole field of mortgages, rural and urban.... In France the spectre of the assignats and the suspension of redeemability of banknotes, from 1848 to 1850, were probably together responsible for the spread of gold and specie clauses.

Gold clauses are not, however, a universal phenomenon. England, despite the suspension of the Bank Act during and after the French wars, remained aloof from them. It was an article of English commercial faith that the pound sterling was as good as gold; the addition of a gold clause to the sterling obligation was regarded as an impairment of the national currency. It is significant that in the Peace Treaties at the end of the late War, England was the only victorious power which forebore to require a gold clause in the reparations provisions. Pounds sterling were demanded and nothing more. It was only after the War that a solitary gold sterling clause made its appearance in English international finance.

Marshall, supra note 8 at para. 14 .

Ibid.

Ibid. at para. 43.

See ibid. at para. 78, McLachlin J. (as she was then), dissenting on other grounds: "While construing the language generously, courts cannot alter the terms of the treaty by exceeding what 'is possible on the language' or realistic,” citing R. v. Badger, [1996] 1 S.C.R. 711 at para. 76; Sioui, supra note 8 at 1069; R. v. Horseman, [1990] 1 S.C.R. 901 at 908. 
principle, therefore, can bar any interpretation that requires the Crown to provide such value in any subsequent year.

A further point may be made. Justice Binnie in Marshall, stated that " $\mathrm{t}] \mathrm{he}$ bottom line is the Court's obligation is to 'choose from among the various possible interpretations of the common intention [at the time the treaty was made] the one which best reconciles" " 47 the interests of the parties. Later in the same case he noted: "Lamer J. in Sioui, ... said it was the Court's duty to search amongst such reasonable interpretations for the one that best accommodates the interests of the parties at the time the treaty was signed." 48 In Mikisew Cree First Nation v. Canada (Minister of Canadian Heritage), Binnie J., writing for the Supreme Court of Canada, emphasized that " $[\mathrm{t}] \mathrm{he}$ interpretation of the treaty 'must be realistic and reflect the intention[s] of both parties, not just that of the [First Nation]." ${ }^{49}$ With respect to any interpretation that the common intention of the parties placed the risk of any decline in the purchasing power of the dollar entirely on the First Nations, the above statements carry the implication that the acceptance of such a risk by the Indians would have somehow reconciled or accommodated their interests. Yet, as noted previously, no reasonable or prudent individual would give equivalent or greater current value in return for a perpetual annuity, at a fixed nominal dollar sum, if there was, at the time of agreement, any recognition that the purchasing power of that annuity could, at some time in the future, be eroded significantly. Justice Binnie in Marshall questions, if "the concept of a disappearing treaty right does justice neither to the honour of the Crown nor to the reasonable expectations of the Mi'kmaq people,"50 how then can agreeing to an annuity that carries the possibility of a greatly diminished and/or continuously diminishing purchasing power, even to the point of insignificance as related to that in existence at the time of treaty, "do justice” to the honour of the Crown or to the reasonable expectations of the signatories to the Numbered Treaties? As observed by Binnie J. in Mikisew with respect to Treaty No. 8: "It is not as though the Treaty 8 First Nations did not pay dearly for their entitlement to honourable conduct on the part of the Crown; surrender of the aboriginal interest in an area larger than France is a hefty purchase price.”51 A similar conclusion must certainly apply to the other Numbered Treaties.

Placing the risks associated with a reduction in the value of the currency used to perform the annuity provisions entirely onto the First Nations could have reconciled or accommodated the interests of the Crown only, as it is only the Crown that could then have stood realistically to benefit should the risk materialize. Further, as only the Crown could, realistically, have had any knowledge or understanding of inflation at the time of treaty, the First Nations signatories cannot be taken to have accepted consciously the risk of it, and it cannot, for the same reason, have been in accord with the honour of the Crown to have placed it on them if, indeed, the Crown had been aware of the nature of this risk at the time of treaty. 
Attention should also be refocused on the statements, noted previously, from Binnie J. in Marshall regarding implied terms in the interpretation of Indian Treaties. ${ }^{52}$ Various interpretations of treaty terms may thus be more or less consistent, or indeed inconsistent, with what can be taken to "assure the efficacy" of that term (or treaty as a whole), with what may "accomplish its intended purpose," and/or with what may "produce a sensible result that accords with the intent of both parties." 53 To the extent, therefore, that the annuity provisions of the Numbered Treaties can be said to have been viewed by both parties as serving a specific purpose or end, conflicting interpretations of the provision may be assessed in terms of how well they serve, promote, or are consistent with that end or purpose. Where the purpose or end is agreed, the interpretation best suited to achieving the desired result, or the interpretation that is most consistent with the achievement of the desired result should, on this standard, govern. Where, among the "various possible interpretations of the common intention" 54 the facts point to an agreed purpose or end with respect to one or more terms of a treaty, it follows that any subsequent interpretation of any such term or terms that is inconsistent with the achievement of that end or purpose cannot be "the one which best reconciles the interests of both parties at the time the treaty was signed" if there exists an alternative interpretation that is consistent.

Historical facts related to the origin, use and purpose of annuities in Indian Treaties would appear to support the following conclusions. ${ }^{55}$

With respect to the pre-confederation period, it may be concluded that annuities were an important, if not the most important, component of the compensation paid to the Indians under the various treaties in exchange for what the Crown viewed as the complete cession of their Indian title. ${ }^{56}$ Beginning in the 1830s, treaty signatories were encouraged to divert some or all of these annual payments to fund items (that is, agricultural implements and

Marshall, supra note 8 at para. 43.

Ibid.

Ibid. at para. 73, citing R. v. Marshall, [1996] N.S.J. No. 246 (QL) at paras. 128-29 [Marshall N.S.]; Sioui, supra note 8 at 1069 .

In addition to the various sources described in the text, the stated conclusions are supported by the results of extensive primary research in this area conducted by the author and Tim Watson.

56 Various matters associated with Indian annuities in the pre-confederation period are discussed in John F. Leslie, Indian Treaty Annuities: The Historical Evolution of Pre-Confederation Government Policy (2005) [unpublished, archived at INAC Claims and Historical Research Centre], prepared for the Research and Analysis Directorate, Indian and Northern Affairs Canada. See also John Sheridan Milloy, The Era of Civilization - British Policy for the Indians of Canada, 1830-1860 (Ph. D. Thesis, University of Oxford, 1978) [unpublished]; R. Surtees, Indian Land Surrenders in Ontario, 1763-1867 (Ottawa: Indian and Northern Affairs Canada, 1984); Robert J. Surtees, "Indian Land Cessions in Upper Canada, 1815-1830” in Ian A.L. Getty \& Antoine S. Lussier, eds., As Long as the Sun Shines and Water Flows: A Reader in Canadian Native Studies (Vancouver: University of British Columbia Press, 1983) 65; The Robinson Treaties (1986) [unpublished, archived at INAC Claims and Historical Research Centre], prepared for the Treaties and Historical Research Centre, Indian and Northern Affairs Canada; James Morrison, The Robinson Treaties of 1850: A Case Study (1996) [unpublished, archived at INAC Claims and Historical Research Centre], report prepared for the Royal Commission on Aboriginal Peoples; John F. Leslie, Commissions of Inquiry into Indian affairs in the Canadas, 1828-1858: Evolving a corporate memory for the Indian Department (Ottawa: Treaties and Historical Research Centre, 1985); John L. Tobias, "Protection, Civilization, Assimilation: An Outline History of Canada's Indian Policy” in Getty \& Lussier, 39; Ray, Miller \& Tough, Bounty, supra note 28; Morris, supra note 28. For the annuity provisions of the pre-Confederation Indian Treaties, see Canada, Indian Treaties and Surrenders from 1680-1890, in Two Volumes (Ottawa: Queen's Printer, 1891). 
tools) and programs (that is, education) deemed essential for the civilization and/or assimilation of the Indians. As such, it may be inferred that Crown officials viewed the extent of diverted payments to be at least sufficient substantially to achieve these purposes. The further inference that these annual payments were meant, and thus considered to be at least a significant contribution to the livelihood of the Indians, whether traditional or agricultural, is also supported.

With reference to the post-confederation Numbered Treaties, it may be concluded, as asserted by Arthur J. Ray, Jim Miller, and Frank Tough, that

[w] hile each treaty has unique and local qualities with respect to livelihood and the benevolence of the Queen, the Crown maintained a consistent position throughout the treaty-making era that the Queen's representatives would assure the sustained livelihood of the First Nations. Indian livelihood was to be secured or enhanced by a treaty relationship, rather than diminished or encroached upon by it. ${ }^{57}$

It may be concluded further that the Indian signatories to the various treaties looked upon the annual payments promised them (in all cases, as stressed by the various Commissioners, to be paid for "as long as the sun shines and the earth remains") as an important component of this commitment. As observed by Arthur J. Ray, for the years spanning the making of the Numbered Treaties, these annual payments were sufficient to provide a native hunter with a family enough income to purchase the equipment necessary to maintain a livelihood, or at least to make a meaningful contribution towards this goal. ${ }^{58}$ It may thus be inferred from the evidence available that the annuities were intended to be of sufficient value to provide a meaningful, if not significant, contribution to the future livelihoods of the First Nations signatories and thus would, at the time of treaty, have been seen and considered by all parties to be so.

To the extent that annuities were viewed at the time of treaty as a meaningful, if not significant, contribution to assisting the Indian signatories in the pursuit of their traditional livelihoods and/or in any future transition away from such traditional practices, the decline in purchasing power held by these annual payments has resulted in the fact that they can no longer be said to serve that purpose in any way. As a means to an end held by the parties at the time of treaty, they are now insignificant. Due to prolonged and significant currency devaluation, annuities serve no current useful purpose, much less the purpose envisaged by the parties at the time of treaty. Moreover, an annuity sufficient to constitute a meaningful, if not significant, contribution to the annual maintenance of a livelihood, to be paid for "as long as the sun shines and the earth remains," is inconsistent entirely with any imputed acceptance, by the First Nations signatories, of the entire risk that such payments could in the future be devalued to such an extent that their annual contribution to the maintenance of a livelihood is negligible at best.

57 Ray, Miller \& Tough, Bounty, ibid. at 214. For further discussion of Indian annuities in the postConfederation Numbered Treaty period, see sources cited in supra note 28. See also Jean Friesen, “Grant Me Wherewith to Make My Living” in Kerry Abel \& Jean Friesen, eds., Aboriginal Resource Use in Canada: Historical and Legal Aspects (Winnipeg: University of Manitoba Press, 1991) 141. 
In the result, given the agreed purpose of the annuity provisions of the Numbered Treaties, any interpretation of these provisions that places the entire risk of inflation on the First Nations cannot be taken to "assure the efficacy" of that term, cannot be seen to "accomplish its intended purpose," and/or does not "produce a sensible result that accords with the intent of both parties." It is only when this risk is placed upon the Crown can the facts support a conclusion that the intended purpose of the treaties has been met, that a sensible result has been achieved, or that efficacy of the term has been assured.

Another argument in support of the conclusions drawn above can be taken from the law and economics literature related to contracts. Richard A. Posner and Andrew M. Rosenfield write:

The distinctive problems of contract law arise when the agreed-upon exchange does not take place instantaneously (for example, A agrees to build a house for B and construction will take several months). The fact that performance is to extend into the future introduces uncertainty, which in turn creates risks. A fundamental purpose of contracts is to allocate these risks between the parties to the exchange. ${ }^{59}$

Where both parties do not perform their obligations under a contract simultaneously, two dangers to the process of exchange arise: opportunism and unforeseen contingencies. ${ }^{60}$ Opportunism, observes Scott Masten:

refers to the willingness of transactors to renege on promises, cheat on agreements, shirk responsibilities, circumvent rules, search out loopholes, or otherwise exploit the vulnerabilities of a trading partner in hopes of eliciting a more favorable distribution of the rents accruing in exchange. (Not everyone is so unprincipled, of course, but bounded rationality makes it difficult to distinguish the trustworthy from the unscrupulous, making guarding against opportunism the prudent course). ${ }^{61}$

Unforeseen contingencies are related to the concept of incomplete contract. Contracts or agreements deal inherently with uncertain or contingent events, those with "[t]he property

Richard A. Posner \& Andrew M. Rosenfield, “Impossibility and Related Doctrines in Contract Law: An Economic Analysis” (1977) 6 J. Legal Stud. 83 at 88 [Posner \& Rosenfield, “Impossibility”]. In Richard A. Posner, Economic Analysis of Law, 5th ed. (New York: Aspen, 1998) at 116 [Posner, Economic Analysis], Posner observes: "The risk-shifting or insurance function of contracts is related to the fact that a contract (other than the truly simultaneous exchange, which is not problematic) by its nature commits the parties to a future course of action; and the future is uncertain.”

60 Posner, Economic Analysis, ibid. at 101.

$61 \quad$ Scott E. Masten, ed., Case Studies in Contracting and Organization (New York: Oxford University Press, 1996) at 6 . The concepts of opportunism and bounded rationality are the two key behavioural assumptions at the base of transaction cost economics. As stated by Oliver E. Williamson, The Economic Institutions of Capitalism: Firms, Markets, Relational Contracting (New York: Free Press, 1985) at 30 [footnotes omitted, emphasis in original]:

What cognitive competencies and what self-interest seeking propensities are ascribed to the human agents in exchange? Transaction cost economics assumes that human agents are subject to bounded rationality, whence behavior is “intendedly rational, but only limitedly so" ... and are given to opportunism, which is a condition of self-interest seeking with guile.”

Transaction costs, notes Masten at 6: "are associated with such activities as bargaining, contracting, and monitoring performance, activities that are not directly productive but which are engaged in only as a consequence of the need to coordinate activities among transactors.” They are, observes Williamson, "the economic equivalent of friction in physical systems" (at 19). 
of not having to occur." 62 Parties, when they enter into contracts or agreements, are thus looking forward, attempting to reduce contingency and delimit the range of acceptable behaviour. As noted by Eric A. Posner:

In their contracts, parties include terms describing performance and governing the main contingencies that affect the value of performance.... A theoretically complete contract would describe all the possible contingencies, but transaction costs — including the cost of negotiating and writing down the terms — and foreseeing low-probability events, render all contracts incomplete. In addition, parties might choose some terms or avoid others for strategic reasons, in order to exploit superior bargaining power or information asymmetries. Thus, contracts are usually quite incomplete. Parties rely on custom, trade usage, and, in the end, the courts to fill out the terms of the contract. ${ }^{63}$

\section{More generally, observes Randy E. Barnett:}

Parties drafting a contract confront a serious knowledge problem. Because they cannot foresee every future event or know precisely how their own purposes may change, they cannot negotiate terms specifically to cover all contingencies. As a result, their manifested agreement will be silent as to these matters. As the duration of a contract is extended, the knowledge problem facing the parties is likely to increase and the completeness of their agreement to decrease. ${ }^{64}$

David D. Friedman also writes that, “contracts never say enough. There is not enough fine print in the world to cover every possible contingency."65 Contracts, especially long-term contracts, are thus incomplete and imperfect documents. ${ }^{66}$ Performance obligations remain more or less imprecise and parties do not, and cannot, anticipate and resolve all future contingencies. Justice Binnie in Marshall, with respect to the 10 March 1760 treaty with the Mi'kmaq, concluded that the "written text is incomplete," ${ }^{\prime 67}$ thus recognizing the possibility in general with respect to treaty interpretation. Insights from the field of law and economics serve only to emphasize the likelihood that all treaties are similarly incomplete (indeed, inherently so, as are all agreements that extend performance into the future).

There are, according to Ian Ayres and Robert Gertner, two distinct ways for a contract to be incomplete:

Anthony Flew, ed., A Dictionary of Philosophy (London: Pan Books, 1979) s.v. “contingency.” Eric A. Posner, “Economic Analysis of Contract Law After Three Decades: Success or Failure?” (2003) 112 Yale L.J. 829 at 832-33. Peter Newman, ed., The New Palgrave Dictionary of Economics and The Law, vol. 1 (London: Macmillan Reference, 1998) s.v. “contracts” at 436: “A contract is said to be complete if the list of conditions on which the actions are based is exhaustive, that is, if the contract provides explicitly for all possible conditions”; Karen Eggleston, Eric A. Posner \& Richard Zeckhauser, "The Design and Interpretation of Contracts: Why Complexity Matters" (2000) 95 Nw. U.L. Rev. 91 at 100: "In the economics literature, a contract is complete when it differentiates among all relevant future states of the world, and a third party, such as a court, can verify, when necessary, which state has occurred."

Supra note 16 at 822.

David D. Friedman, Law's Order: What Economics Has to Do with Law and Why It Matters (Princeton: Princeton University Press, 2000) at 147.

Robert E. Scott, “A Theory of Self-Enforcing Indefinite Agreements” (2003) 103 Colum. L. Rev. 1641 at 1641 [footnotes omitted]: "All contracts are incomplete. There are infinite states of the world and the capacities of contracting parties to condition their future performance on each possible state are finite.” Marshall, supra note 8 at para. 41. 
First, a contract may fail to specify the parties' duties for specific future contingencies. For example, a contract for the construction of a third floor to a house may not state the parties' respective rights and responsibilities should the entire house burn down before construction is started. Since construction of a third floor is impossible (without the lower two floors), the contract does not cover the contingency of the house burning down.

The second form of contractual incompleteness is more subtle. A contract may also be incomplete in that it is insensitive to relevant future contingencies. Under this second form of contractual incompleteness, parties' duties are fully specified, but the contracts are incomplete because those specified duties are not tailored to economically relevant future events.... For example, consider a contract that simply obligates one party to construct a garage adjacent to a house. On the face this contract imposes a duty to build a garage whether or not the adjacent house burns down before construction of the garage is complete. The contract is incomplete in this second sense, however, because the duty to build a garage is not sufficiently dependent on future contingencies. If the adjacent house burns down, the parties probably would want to adjust the terms of the contract. Such contracts we call insufficiently state-contingent. ${ }^{68}$

\section{Richard A. Posner also writes:}

The task for a court asked to interpret a contract to cover a contingency that the parties did not provide for is to imagine how the parties would have provided for the contingency if they had decided to do so. Often there will be clues in the language of the contract. But often there will not be, and then the court may have to engage in economic thinking - may have to decide what the most efficient way of dealing with the contingency is. For this is the best way of deciding how the parties would have provided for it. Each party, it is true, is interested just in his own profit, and not in the joint profit; but the larger the joint profit is, the bigger the "take" of each party is likely to be. So they have a mutual interest in minimizing the cost of performance. The court can make use of this interest to fill out a contract along lines that the parties would have approved at the time of making the contract. ${ }^{69}$

If the annuity provisions of the Numbered Treaties do not make an explicit allocation of the risks associated with a decline in the purchasing power of the dollar then, as with the

Ian Ayres \& Robert Gertner, "Filling Gaps in Incomplete Contracts: An Economic Theory of Default Rules” (1989) 99 Yale L.J. 87 at 92, n. 29 [citations omitted].

Posner, Economic Analysis, supra note 59 at 105. These statements would appear to provide an economic justification for the "of course" test and the role of the "officious bystander," as applied to the interpretation of Indian treaties by Binnie J. in Marshall, supra note 8. Posner \& Rosenfield, "Impossibility," supra note 59 at 88, notes one of the fundamental purposes of contract law as being "to reduce the costs of contract negotiation by supplying contract terms that the parties would probably have adopted explicitly had they negotiated over them," and point to Bentham as a precursor of the concept. See John Bowring, ed., The Works of Jeremy Bentham, vol. 3 (Edinburgh: W. Tait, 1843) at 190-91 [footnotes omitted]:

[O]bligations may be distinguished into original and adjective. I call those original, of which express mention is made in the contract itself: I call those adjective, which the law thinks proper to add to the first. The first turn upon events which the contracting parties have foreseen; the others upon events which they could not foresee.

It is thus that in every country the law has supplied the short-sightedness of individuals, by doing for them what they would have done for themselves, if their imagination had anticipated the march of nature. 
Mi’kmaq Treaty in Marshall, "the written text is incomplete."70 They fail to specify the rights and duties of the parties in the event of inflation.

Where the parties have failed to allocate risks explicitly, law and economics suggests that liability fall on the party best able to avoid, insure against, or bear the cost. ${ }^{71}$ As noted by Ayres and Gertner, "[w]hile ex post each party will have economic incentives to shift costs to the other side, ex ante the parties have an incentive to place the risks on the least-cost avoider."72 According to Richard A. Posner and Andrew M. Rosenfield, the least cost avoider or superior risk bearer in this sense is the party that would have incurred lower risk appraisal and transaction costs. ${ }^{73}$ The party with better knowledge of the probability and potential seriousness of the risk in question is the party with lower risk-appraisal costs. ${ }^{74}$ The party with lower transaction costs is the party best capable of pooling or diversifying the risk or risks. $^{75}$

On this analysis, it cannot be doubted that Canada is the least cost avoider or superior risk bearer with respect to any inflation risk associated with the annuity provisions of the Numbered Treaties not allocated for by the parties explicitly. As noted above, only the Crown could have had any knowledge or understanding of inflation and the various risks associated with fixed sum payments of money under long-term agreements. As such, only Canada was in a position to recognize the risk, and thus the only party that could have been able to take steps to insure or mitigate that risk. It was not only the superior risk bearer and least cost avoider, it was also the only party that could have had any recognition that there was a risk to bear or avoid.

Further, Canada should have been aware of the possibility for future inflation yet, by the terms used in the annuity provisions, shifted this risk entirely onto the First Nations signatories without having informed them of the risk, and thus without having obtained their informed consent to accept such a risk, the honour of the Crown would not have been upheld. Given the circumstances, such action by Canada would have been taken with full knowledge that the First Nations (with their, at best, limited experience with money) could have had no comprehension of the risk that was being placed on them, and with full knowledge that any onset of inflation would have decreased considerably, and entirely at the expense of the First Nations, the burden of the annuity provisions as taken on by the Crown at the time of treaty. If not a clear example of sharp dealing, such action must carry at least the appearance of it. It most certainly would not have been honourable.

One more point may be made with respect to the incomplete nature of contracts and agreements. As observed by Richard Craswell:

See Posner, Economic Analysis, supra note 59 at 101-54; Posner \& Rosenfield, “Impossibility,” supra note 59.

Ayres \& Gertner, supra note 68 at 89, n. 18, citing Anthony T. Kronman, "Mistake, Disclosure, Information, and the Law of Contracts" (1978) 7 J. Legal Stud. 1.

Posner \& Rosenfield, “Impossibility,” supra note 59 at 91.

Ibid. at 91-92.

Ibid. 
More fundamentally, though, the completeness of a contract also depends on how "completeness" is defined. In law, we sometimes say that a contract is "complete" if it leaves no gaps to be filled, meaning that it specifies a determinate outcome in every possible future state. By this definition, however, the completeness of a contract will depend on the rules of interpretation that are applied. For example, a contract that says the seller will deliver 100 widgets on July 1 could be considered "complete" (in the sense of not leaving any gaps) if it is interpreted to mean that the seller must deliver those widgets on July 1 regardless of anything else that might happen. But this contract could also be described as "incomplete" if it is instead interpreted as not saying anything one way or the other about what happens if (for example) the closure of the Suez Canal prevents the seller from delivering the widgets on time. Under that interpretation, the contract leaves a "gap" by failing to specify a result in those future states of the world in which the Suez Canal is closed. Thus, if incompleteness is defined by whether the contract leaves gaps, we cannot even classify a contract as "complete" or as "incomplete" without first choosing between the various competing interpretations. ${ }^{76}$

With respect to the annuity provisions of the Numbered Treaties, Canada has, as noted, viewed its obligation to be that of rendering annually to the Indians the nominal amount of $\$ 4, \$ 5, \$ 15$, or $\$ 25$ stated in the treaty in such money as the law provides as amounting to $\$ 4, \$ 5, \$ 15$, or $\$ 25$ at the time of payment. In other words, the Indian signatories to the treaties are to be paid the nominal amounts specified in the treaty, in current legal tender, "regardless of anything else that might happen,"77 in this case, any severe loss in purchasing power in the nominal sums provided due to inflation. Canada has thus viewed the treaty text as entirely "complete" on this matter.

To stress again, however, the Supreme Court of Canada has emphasized that "the goal of treaty interpretation is to choose from among the various possible interpretations of common intention the one which best reconciles the interests of both parties at the time the treaty was signed." ${ }^{78}$ In the result, the interpretation of the annuity provisions of the Numbered Treaties adopted by Canada, that the nominal amounts specified in the treaty are to be paid in current legal tender "regardless of anything else that might happen,"79 can be sustained only to the extent that this interpretation is consistent with this interpretive standard. It has been suggested that it cannot.

\section{HONOUR OF THE CROWN}

Keith S. Rosenn observes:

The effects of chronic inflation are particularly pernicious with respect to three types of legal arrangements: (1) credit transactions extending over substantial periods of time, (2) insurance, and (3) pensions and annuities.... [T]hese three areas have been the object of special legislation designed to counteract the adverse effects of inflation. ${ }^{80}$

Richard Craswell, "Incomplete Contracts and Precautions” (8 January 2005), online: Association of American Law Schools <http://www.aals.org/am2005/saturdaypapers/130craswell.pdf > at 3-4 [footnotes omitted, emphasis in original].

Ibid.

Marshall, supra note 8 at para. 78; Sioui, supra note 8 at 1068-69.

Supra note 76.

Keith S. Rosenn, Law and Inflation (Philadelphia: University of Pennsylvania Press, 1982) at 167. 
He continues that "[a]s a class, pensioners and annuitants are likely to suffer most from inflation. Members of this class often discover that inflation so reduces the purchasing power of their benefits that ... governments with severe inflation adopt measures to readjust pensions and annuities for inflation." ${ }^{\prime 1}$

As indicated by the annual percentage change in the Consumer Price Index (CPI) in Canada since 1915, fluctuating periods of inflation and deflation between 1915 and 1939 have given way to persistent annual increases in inflation since 1940, including the significant annual increases recorded during the 1970s, 1980s, and early 1990s. ${ }^{82}$ As stated by Powell:

Inflation erodes the purchasing power of money. Even with a low annual inflation rate of 2 per cent ... a dollar will lose half of its purchasing power in approximately 35 years. When the consumer price index (CPI) is used to measure inflation, the average annual rate of inflation in Canada since 1914 is 3.2 per cent. Thus, the Canadian dollar lost more than 94 per cent of its value between 1914 and 2005.... Alternatively, one dollar in 1914 would have the purchasing power of \$17.75 in 2005 dollars.

While consumer price data prior to 1914 are unavailable, a broader measure of inflation, the gross domestic product (GDP) deflator, is available back to $1870 \ldots$... While the CPI and GDP deflator can diverge, they tend to move together over time. Since 1870, with annual GDP inflation averaging 3.6 per cent, the Canadian dollar has lost more than 96 per cent of its value. Again, this is equivalent to saying one Canadian dollar in 1870 would have the purchasing power of roughly $\$ 26.70$ in today’s [2005] money. ${ }^{83}$

Annuities under the Numbered Treaties have not been raised or adjusted to counter or compensate for the devastating effects of inflation on the purchasing power of the promised annual payments. This fact may be contrasted with the varying levels of protection against inflation that have been provided by Parliaments and governments since the early 1940s with respect to public and public service pensions.

$81 \quad$ Ibid. at 168.

82 "Consumer Price Index, historical summary: (1988 to 2007)," online: Statistics Canada <http://www40.statcan.ca/10/cst01/econ46a/htm>.

83 Powell, supra note 31 at 88. According to an inflation calculator, a fixed "basket" of consumer goods and services (including food, shelter, furniture, clothing, transportation, and recreation) that cost \$5.00 in 1914 would cost $\$ 93.08$ in 2007, a 1,761.67 percent change over the 93-year time period (an average annual inflation of 3.2 percent). See Inflation Calculator, online: Bank of Canada <http://www.bankof canada.ca/en/rates/inflation_calc.html>. The decline of the dollar in terms of gold has been even more dramatic. See Powell at 90-91 [footnotes omitted]:

One ounce of gold was worth \$20.67 in 1854 when the Currency Act was passed in the Province of Canada, fixing the Canadian dollar at par with the U.S.-dollar, equivalent to 23.22 grains of gold. In 1933, the statutory price of gold in Canada was the same, \$20.67 per ounce. The official U.S.-dollar price of gold was raised to US\$35 per ounce (roughly the same in Canadian dollars) on 31 January 1934 when President Roosevelt's administration took steps to reflate the U.S. economy during the Great Depression. The US\$35 per ounce price remained fixed until 15 August 1971 when President Nixon broke the link between the U.S. dollar and gold. In Canadian dollars, one ounce of gold was worth about $\$ 35.40$ on that date. In late October 2005, the market price of an ounce of gold stood at roughly \$550 in Canadian funds (or about US\$465). In other words, the Canadian dollar has lost about 96 per cent of its value in terms of gold since 1933, with much of this occurring since August 1971, while the U.S. dollar has lost roughly 95 per cent of its value. As of November 2008, the price of gold has been hovering around CDN\$900 per ounce, see online: Gold Price <http://www.goldprice.org>. 
The demand for public old age pensions in Canada began soon after confederation. ${ }^{84}$ By the turn of the twentieth century, sales of individual annuities were an important element of the business being done by insurance companies in Canada. Investigations undertaken by the 1906 Royal Commission on Insurance in Canada, however, revealed various frauds, conflicts of interest, and serious mismanagement of insurance company funds. Public confidence was shaken considerably and insurance company sales of annuities dropped off sharply. The Government Annuities Act, $1908,{ }^{85}$ offered an alternative to entrusting the savings of Canadians to private insurance companies. The GAA made available a much cheaper pensions scheme than those offered by the private sector, as administration costs would be borne by government, not charged against the funds contributed. Other aspects of the individual contract were also superior to that on offer from the insurance companies. The plan was entirely voluntary being, in essence, a personal savings plan for the regular setting aside of funds to meet future needs. All contributions were to be paid by the beneficiaries with no assistance from employers or government. The GAA did nothing for those already old and in need. Moreover, most working Canadians were in no financial position to purchase annuities, no matter how favourable the terms.

In the event, the GAA failed to silence the call for public pensions. Prospects for a statesponsored pension plan were examined in 1912 by the House of Commons Committee on Old Age Pensions. The report was never acted on, but did reveal that existing private pension plans were restricted almost exclusively to the federal public service, banks, and railways. ${ }^{86}$

Public interest in the matter waned during the war years, but revived quickly afterwards. ${ }^{87}$ A House of Commons committee appointed in 1924 to investigate the establishment of old age pensions recommended the following year a non-contributory plan paying \$240 per year (\$20 per month) to those aged 70 and over, subject to a strict means test, costs to be shared between federal and provincial governments. The recommendations of the committee formed the basis for the Old Age Pensions Act of $1927 .{ }^{88}$

Pensions were not a major political issue during the 1930s. By the outbreak of World War II, however, the resulting economic expansion would focus criticism on the 1927 OAP, particularly with respect to the amount (too small), the means test (too strict), and the age of eligibility (too high). Pressures to raise the $\$ 20$ per month payment became intense. After initially resisting an increase, Finance Minister J.L. Ilsley advised the House on 24 July 1943

84 See generally, Dennis Guest, The Emergence of Social Security in Canada (Vancouver: University of British Columbia Press, 1980) at 34-35.

85 S.C. 1908, c. 5 [GAA].

86 See Harry Weitz, The Pension Promise: The Past and Future of Canada's Private Pension System (Scarborough: Carswell, 1992) at 26:

The most extensive coverage was in federal government employment. Formal retirement plans were in force for all federal employees in permanently established positions, as well as for judges under the Judges Act of 1906; the military under the Militia Pensions Act of 1901; the Royal Canadian Mounted Police under the Mounted Police Officers’ Pension Act of 1906; and ships' pilots under the Pilotage Act of 1886 and the Canada Shipping Act of 1906.

87 See Guest, supra note 84; Elisabeth Wallace, “Old Age Security in Canada: Changing Attitudes” (1952) 18 Canadian Journal of Economics and Political Science 125 at 127.

88 R.S.C. 1927, c. 156 [OAP]. An analysis of the 1927 OAP can be found in Kenneth Bryden, Old Age Pensions and Policy-Making in Canada (Montreal: McGill-Queen's University Press, 1974) at 61-80. The OAP of 1927, s. 8(e), excluded Indians as defined under the Indian Act, R.S.C. 1906, c. 81, s. 2(f). 
that pensions would be increased to \$25 a month by Order in Council under the War Measures Act, $1914 .^{89}$ The amount was raised to \$30 in 1947 and again, in 1949, to \$40 per month.

These increases did not result in any significant change to the 1927 OAP, but "merely adjusted it in some measure to the rising prices, living standards, and government revenues of the period." ${ }^{90}$ Meeting other criticisms would pose more serious problems (reducing the age of eligibility would increase costs significantly) or require a complete restructuring of the existing plan (ending the means test). After much political wrangling and a constitutional amendment that allowed Ottawa to develop a centralized public pension plan, a compromise scheme was enacted in 1951 which eliminated the means test for Canadians over the age of 70 (The Old Age Security Act) ${ }^{91}$ and put in place a new means-test plan for the 65 to 69 age group (The Old Age Assistance Act). ${ }^{92}$ The basic pension remained at $\$ 40$ per month.

Within five years, however, the effects of inflation once again created pressures to increase the monthly benefit. The Liberal government eventually announced a $\$ 6$ per month (15 percent) increase in 1956. The odd figure, and the perceived inadequacy of the resultant monthly payment of $\$ 46$, turned out to be a political miscalculation that would be exploited by the Diefenbaker Tories in their successful election campaign of 1957. One of the first initiatives of the new minority government were amendments to the 1951 pensions acts that increased both the universal pension and the maximum means-test pension by a further $\$ 9$ to $\$ 55$ a month. Both pensions were increased a further \$10 per month on the eve of the 1962 election, and another \$10 to a total of \$75 per month in 1963.

Parliament in 1959 also passed the Public Service Pension Adjustment Act, ${ }^{93}$ putting into place a permanent cost-of-living increase in pensions paid under the Public Service Superannuation Act of $1953 .{ }^{94}$ The increase, assumed entirely by the federal government, was designed to provide compensation due to post-war inflation. ${ }^{95}$

All parties during the 1962 and 1963 election campaigns were committed to the principle of a national, contributory, earnings-related pension plan. The Liberals, after being returned

S.C. 1914 (2d Sess.), c. 2. Bryden, ibid. at 94-95: "The case for increasing the pension was particularly strong, since both the cost of living and standard of living were rising in the country: the cost of living index $(1935-39=100)$ rose from 119.5 in 1945 to 166.5 in 1950; per capita personal income (in 1949 constant dollars) from $\$ 755$ to $\$ 1,130$.” Bryden, ibid. at 104.

R.S.C. 1985, c. O-9.

S.C. 1951, c. 55; The Old Age Security Act, S.C. 1951 (2d Sess.) c. 18. The essentials of the scheme are discussed in Bryden, supra note 88. In contrast to the $O A P$ of 1927, Indians were no longer excluded. S.C. 1959, c. 32 [PSPAA]. The PSPAA of 1954 replaced the Civil Service Superannuation Act, S.C. 1924, c. 69. A formal program providing for civil service pensions was introduced three years after confederation (An Act for better ensuring the efficiency of the Civil Service of Canada, by providing for the Superannuation of persons employed therein, in certain cases, S.C. 1870 (3d Sess.), c. 4, discussed by Weitz, supra note 86 at 16-17). "History of the Public Service Pension Plan," noted the fact that the PSSA of 1954 made pension benefits a right upon cessation of employment, rather than a grant approved by the Governor in Council, marking a major change in pension policy, online: Treasury Board of Canada Secretariat < http://www.tbs-sct.gc.ca/hr-rh/bp-rasp/pensions/pensionfacts-info pensions/historyhistoire_eng.asp $>$ [Treasury Board].

S.C. $1952-53$, c. 47.

Treasury Board, supra note 93. 
to power with a minority government in April 1963, tabled a proposal for a contributory pension plan that would complement the existing universal monthly Old Age Security (OAS) benefit of $\$ 75$ per month. The proposal would undergo much revision and be the subject of tortured negotiations with the provinces, particularly Quebec. The result was the Canada Pension Plan (CPP) of $1965 .^{96}$ Provisions providing for automatic adjustments due to inflation were integral to the new plan, replacing the various ad hoc adjustments that had been undertaken previously. Benefits were to rise in line with the cost of living, but only to a maximum of 2 percent per year.

It soon became apparent, however, that the low and stable inflationary expectations underlying the plan were inconsistent with economic realities. ${ }^{97}$ Almost immediately after the CPP/QPP was introduced, inflation moved sharply upwards. By 1969, increases in the cost of living had far exceeded the maximum 2 percent limit on the increase in benefits. Revisions to the OAS and Guaranteed Income Supplement (GIS) were made in 1970, 1972, and 1973 and to the CPP/Quebec Pension Plan (QPP) in 1973. ${ }^{98}$ All involved some combination of benefits increases and adjustments to the indexation scheme. By January of 1974, the 2 percent limit on cost of living increases had been discarded for all three pensions in favour of full indexation to the CPI. Adjustments to public service pensions followed a similar path. Coordination of the PSPAA with the CPP/QPP was done in 1966. Indexation of public service pensions was introduced through the Supplementary Retirement Benefits Act of $1970,{ }^{99}$ subject to a 2 percent ceiling. The latter ceiling was removed in 1974, at which time, as with the OAS, GIS, and CPP/QPP, public service pension benefits were indexed fully to the CPI. All have remained so ever since.

The Supreme Court of Canada has stressed the importance of upholding the honour of the Crown with respect to the interpretation and implementation of treaties. In Haida Nation $v$. British Columbia (Minister of Forests), a unanimous Court stated:

The honour of the Crown is always at stake in its dealings with Aboriginal peoples: see for example R. $v$. Badger, [1996] 1 S.C.R. 771, at para. 41; R. v. Marshall, [1999] 3 S.C.R. 456. It is not a mere incantation, but rather a core precept that finds its application in concrete practices.

In all its dealings with Aboriginal peoples, from the assertion of sovereignty to the resolution of claims and the implementation of treaties, the Crown must act honourably.

Canada Pension Plan, S.C. 1964-65, c. 51. The Quebec Pension Plan (QPP), introduced concurrently, was wholly compatible with the Canada Pension Plan (CPP), but administered separately. See Bryden, supra note 88.

See Ann Finlayson, Whose Money Is It Anyway?: The Showdown on Pensions (Markham: Viking, 1988) (discussing the economic and political environment in the years immediately subsequent to the establishment of the CPP/QPP).

See Bryden, supra note 88 at 175-82.

R.S.C. 1985, c. S-24. 
The honour of the Crown also infuses the processes of treaty making and treaty interpretation. In making and applying treaties, the Crown must act with honour and integrity, avoiding even the appearance of "sharp dealing” (Badger, at para. 41).

Treaties serve to reconcile pre-existing Aboriginal sovereignty with assumed Crown sovereignty, and to define Aboriginal rights guaranteed by s. 35 of the Constitution Act, 1982. Section 35 represents a promise of rights recognition, and "[i]t is always assumed that the Crown intends to fulfil its promises" (Badger, supra, at para. 41). This promise is realized and sovereignty claims reconciled through the process of honourable negotiation. It is a corollary of s. 35 that the Crown act honourably in defining the rights it guarantees and in reconciling them with other rights and interests. ${ }^{100}$

Similar statements were made by the Supreme Court of Canada in Taku River Tlingit First Nation v. British Columbia (Project Assessment Director): “[t]he Crown's honour cannot be interpreted narrowly or technically, but must be given full effect in order to promote the process of reconciliation mandated by s. 35(1).”" ${ }^{\text {„101 }}$ Similarly, Binnie J. for the Supreme Court of Canada in Mikisew stressed that "the honour of the Crown infuses every treaty and the performance of every treaty obligation.",

The numerous adjustments and compensations for inflation made to public and public service pensions stand in stark contrast to the complete lack of any such efforts to counter or compensate for the devastating effects of inflation on the purchasing power of the promised annual payments under the Numbered Treaties. Indeed, as noted previously, the cost to the Crown in real terms has been reduced in direct correspondence to the reduction in real benefits received by the First Nations signatories. These benefits to the Crown have not been insignificant. As noted by Ray, the issue of annuities loomed quite large in the financial situation of Dominion governments prior to 1900:

\begin{abstract}
The problem for the government was that the development of the North-West Territories was an expensive undertaking, and the conclusion of Treaties 1-7 added considerably to these expenditures. Between 1868 and 1881 they accounted for over 11 per cent of the total for the new territory, and by 1885 Indian Department expenses accounted for nearly 15 per cent of the total federal expenditures under supply bills. These spiralling costs provoked prolonged and heated debates between MPs in the House whenever the government introduced Indian Department supply bills. In these debates federal politicians expressed their shock and alarm over the magnitude of the financial burden that the government had assumed in Treaties 1 through $7 .{ }^{103}$
\end{abstract}

A breakdown of Crown expenditures on Indian annuities as related to total federal government expenditures between 1867 and 1900 is set out in Appendix A to this article. ${ }^{104}$ Although far from precise, given the lack of specific information, Crown expenditures on treaty annuities, as a percentage of total federal government expenditures, averaged

2004 SCC 73, [2004] 3 S.C.R. 511 at paras. 16-20. 2004 SCC 74, [2004] 3 S.C.R. 550 at para. 24.

Mikisew, supra note 49 at para. 57.

Supra note 25 at 34 [footnotes and figures omitted].

The author would like to thank Phil Comeau of HMCG for his assistance in compiling the information contained in this table. 
approximately 0.2 percent over the period. At the time of Treaty No. 8 in 1899, for example, expenditures on treaty annuity payments totalled some \$164,336, as against total federal government expenditures of $\$ 139,068,542$, or 0.12 percent of the latter amount. ${ }^{105}$ For purposes of comparison, total federal government expenditures in 2007 totalled, in millions, $\$ 229,460 .{ }^{106}$ Of this amount, 0.12 percent equals some $\$ 268.31$ million.

It cannot be honourable for the Crown to deny appropriate adjustments for inflation with respect to treaty annuity payments while legislating and/or regulating such adjustments with respect to similar fixed, long-term commitments to its own servants and employees and, indeed, the Canadian public at large. The very same arguments of justice and fairness that compelled Crown governments to adjust pension benefits to compensate for the insidious effects of inflation must apply with even greater force to annuities promised with great solemnity to the signatories of the Numbered Treaties "for as long as the sun shines and the earth remains.” It cannot be honourable, nor is it just, for the Crown to have benefited, and continue to benefit, at the direct expense of the First Nations signatories from an economic condition beyond the knowledge of the latter at the time the treaties were entered into, a persistent condition that has reduced into meaninglessness, and continues to reduce further, the extent of an obligation assumed freely by Canada and intended clearly to be of value, in perpetuity, to the intended recipients. The effects of inflation on public and public service pensions was recognized and alleviated by direct and frequent action by various Crown governments. The honour of the Crown commanded, and continues to command, no less with respect to annuities promised under the Numbered Treaties.

\section{Conclusion}

It has been suggested that the stability of treaty annuities in terms of purchasing power (and the consequent placement of the risk of any decline in the buying power of the dollar from that existing at the time of treaty on the Crown) must, if not found explicitly within the terms of the Numbered Treaties as the expressed intent of the parties (argument from express terms), be implied as a reflection of their unexpressed intent (argument from implied terms). Any interpretation that entails this risk of inflation being assumed by the First Nations signatories must therefore be based entirely on factors other than the common intention of the parties to the treaties.

It has been suggested further that it cannot have been, or continue to be, honourable for the Crown to deny appropriate adjustments for inflation with respect to treaty annuity payments while legislating and/or regulating such adjustments with respect to similar fixed, long-term commitments to its own servants and employees and, indeed, the Canadian public at large. The very same arguments of justice and fairness that compelled Crown governments to adjust pension benefits to compensate for the insidious effects of inflation must apply with even greater force to annuities promised with great solemnity to the signatories of the Numbered Treaties "for as long as the sun shines and the earth remains." 
In the result, it has been suggested that the obligation of Canada under the annuity provisions of the Numbered Treaties must be to deliver annually a nominal amount in legal tender having a value, in terms of purchasing power, equivalent to that possessed by $\$ 4$, $\$ 5$, $\$ 15$, or $\$ 25$ at the time the various treaties were entered into. 


\section{APPENDIX A: INDIAN AFFAIRS ANNUITIES EXPENDITURES 1867-1900}

\begin{tabular}{|c|c|c|c|c|c|}
\hline \multirow[t]{2}{*}{ Year } & \multicolumn{2}{|r|}{ Dominion of Canada } & \multicolumn{3}{|c|}{ Indian Affairs } \\
\hline & $\begin{array}{c}\text { Total } \\
\text { Expenditures } \\
\text { (\$) }\end{array}$ & Reference & $\begin{array}{c}\text { Annual Indian } \\
\text { Annuity } \\
\text { Expenditures } \\
\text { (\$) } \\
\end{array}$ & Reference & $\begin{array}{c}\% \text { of Total } \\
\text { Expenditures }\end{array}$ \\
\hline $\begin{array}{c}\text { 1865-66 } \\
\text { (Fiscal Year } \\
\text { Ended } 30 \text { June } \\
\text { 1866) }\end{array}$ & $12,418,105.84$ & $\begin{array}{l}\text { Legislature, "Public Accounts of the } \\
\text { Province of Canada, for the Fiscal Year } \\
\text { Ended 30th June, 1866" by A.T. Galt in } \\
\text { Sessional Papers, No. } 2 \text { (1867) at ix. }\end{array}$ & $22,110.00$ & $\begin{array}{l}\text { Legislature, "Public Accounts of the } \\
\text { Province of Canada, for the Fiscal Year } \\
\text { Ended 30th June, 1866" by A.T. Galt in } \\
\text { Sessional Papers, No. } 2 \text { (1867) at i-135. }\end{array}$ & 0.18 \\
\hline $\begin{array}{c}1866-67 \\
\text { (Fiscal Year } \\
\text { Ended } 30 \text { June } \\
\text { 1867) }\end{array}$ & $14,727,282.33$ & $\begin{array}{l}\text { Legislature, “Public Accounts of the } \\
\text { Province of Canada, for the Fiscal Year } \\
\text { Ended 30th June, 1867” by John Rose } \\
\text { in Sessional Papers, No. } 2 \text { (1868) at ix. }\end{array}$ & $35,420.00$ & $\begin{array}{l}\text { Legislature, "Public Accounts of the } \\
\text { Province of Canada, for the Fiscal Year } \\
\text { Ended 30th June, 1867” by John Rose } \\
\text { in Sessional Papers, No. } 2 \text { (1868) at i- } \\
107 .\end{array}$ & 0.24 \\
\hline $\begin{array}{c}\text { 1867-68 } \\
\text { (Fiscal Year } \\
\text { Ended } 30 \text { June } \\
\text { 1868) }\end{array}$ & $18,417,172.03$ & $\begin{array}{l}\text { Legislature, "Public Accounts of the } \\
\text { Dominion of Canada, for the Fiscal } \\
\text { Year Ended 30th June, } 1868 \text { ” by John } \\
\text { Rose in Sessional Papers, No. } 4 \text { (1869) } \\
\text { at 4-17. }\end{array}$ & $40,120.00$ & $\begin{array}{l}\text { Legislature, "Public Accounts of the } \\
\text { Dominion of Canada, for the Fiscal } \\
\text { Year Ended 30th June, 1868” by John } \\
\text { Rose in Sessional Papers, No. } 4 \text { (1869) } \\
\text { at ii-50. }\end{array}$ & 0.22 \\
\hline $\begin{array}{c}\text { 1868-69 } \\
\text { (Fiscal Year } \\
\text { Ended } 30 \text { June } \\
\text { 1869) }\end{array}$ & $29,913,170.84$ & $\begin{array}{l}\text { Parliament, "Public Accounts of the } \\
\text { Dominion of Canada, for the Fiscal } \\
\text { Year Ended 30th June, 1869" by F. } \\
\text { Hincks in Sessional Papers, No. } 7 \\
\text { (1870) at xiii. }\end{array}$ & $42,420.00$ & $\begin{array}{l}\text { Parliament, "Public Accounts of the } \\
\text { Dominion of Canada, for the Fiscal } \\
\text { Year Ended 30th June, 1869" by F. } \\
\text { Hincks in Sessional Papers, No. } 7 \\
\text { (1870) at ii-63. }\end{array}$ & 0.14 \\
\hline $\begin{array}{c}1869-70 \\
\text { (Fiscal Year } \\
\text { Ended } 30 \text { June } \\
\text { 1870) }\end{array}$ & $22,020,766.88$ & $\begin{array}{l}\text { Parliament, "Public Accounts of the } \\
\text { Dominion of Canada, for the Fiscal } \\
\text { Year Ended 30th June, 1870" by F. } \\
\text { Hincks in Sessional Papers, No. } 1 \\
\text { (1871) at i-5. }\end{array}$ & & No Specific Information Available & \\
\hline $\begin{array}{c}\text { 1870-71 } \\
\text { (Fiscal Year } \\
\text { Ended } 30 \text { June } \\
\text { 1871) }\end{array}$ & $24,771,016.05$ & $\begin{array}{l}\text { Parliament, "Public Accounts of the } \\
\text { Dominion of Canada, for the Fiscal } \\
\text { Year Ended 30th June, 1871" by F. } \\
\text { Hincks in Sessional Papers, No. } 1 \\
\text { (1872) at xix. }\end{array}$ & & No Specific Information Available & \\
\hline $\begin{array}{c}1871-72 \\
\text { (Fiscal Year } \\
\text { Ended } 30 \text { June } \\
\text { 1872) } \\
\end{array}$ & $31,321,164.58$ & $\begin{array}{c}\text { Parliament, "Public Accounts of } \\
\text { Canada, for the Fiscal Year Ended 30th } \\
\text { June, 1872" by S.L. Tilley in Sessional } \\
\text { Papers, No. } 2 \text { (1873) at xvii. }\end{array}$ & & No Specific Information Available & \\
\hline $\begin{array}{c}1872-73 \\
\text { (Fiscal Year } \\
\text { Ended } 30 \text { June } \\
\text { 1873) }\end{array}$ & $35,287,250.31$ & $\begin{array}{c}\text { Parliament, "Public Accounts of } \\
\text { Canada, for the Fiscal Year Ended 30th } \\
\text { June, 1873" by R.J. Cartwright in } \\
\text { Sessional Papers, No. 1 (1874) at xiia. }\end{array}$ & $\begin{array}{c}8,502.00 \\
\text { (Note: Treaties } \\
1-2)\end{array}$ & $\begin{array}{l}\text { Parliament, "Public Accounts of } \\
\text { Canada, for the Fiscal Year Ended 30th } \\
\text { June, 1873" by R.J. Cartwright in } \\
\text { Sessional Papers, No. } 1 \text { (1874) at iii-33. }\end{array}$ & 0.02 \\
\hline
\end{tabular}




\begin{tabular}{|c|c|c|c|c|c|}
\hline \multirow[t]{2}{*}{ Year } & \multicolumn{2}{|r|}{ Dominion of Canada } & \multicolumn{3}{|c|}{ Indian Affairs } \\
\hline & $\begin{array}{c}\text { Total } \\
\text { Expenditures } \\
\text { (\$) }\end{array}$ & Reference & $\begin{array}{l}\text { Annual Indian } \\
\text { Annuity } \\
\text { Expenditures } \\
\text { (\$) }\end{array}$ & Reference & $\begin{array}{c}\text { \% of Total } \\
\text { Expenditures }\end{array}$ \\
\hline $\begin{array}{c}\text { 1873-74 } \\
\text { (Fiscal Year } \\
\text { Ended } 30 \text { June } \\
\text { 1874) }\end{array}$ & $36,524,876.20$ & $\begin{array}{l}\text { Parliament, "Public Accounts of } \\
\text { Canada, for the Fiscal Year Ended 30th } \\
\text { June, 1874" by R.J. Cartwright in } \\
\text { Sessional Papers, No. } 1 \text { (1875) at xiia. }\end{array}$ & $\begin{array}{c}47,539.16 \\
\text { (Note: Treaties } \\
1-3)\end{array}$ & $\begin{array}{c}\text { Parliament, "Public Accounts of } \\
\text { Canada, for the Fiscal Year Ended 30th } \\
\text { June, 1874" by R.J. Cartwright in } \\
\text { Sessional Papers, No. } 1 \text { (1875) at iii-20. }\end{array}$ & 0.13 \\
\hline $\begin{array}{c}\text { 1874-75 } \\
\text { (Fiscal Year } \\
\text { Ended } 30 \text { June } \\
\text { 1875) }\end{array}$ & $51,350,844.20$ & $\begin{array}{l}\text { Parliament, "Public Accounts of } \\
\text { Canada, for the Fiscal Year Ended 30th } \\
\text { June, 1875" by R.J. Cartwright in } \\
\text { Sessional Papers, No. } 1 \text { (1876) at xvii. }\end{array}$ & $\begin{array}{c}38,140.00 \\
\text { (Note: Treaties } \\
1-3 \text { ) }\end{array}$ & $\begin{array}{c}\text { Parliament, "Public Accounts of } \\
\text { Canada, for the Fiscal Year Ended 30th } \\
\text { June, 1875" by R.J. Cartwright in } \\
\text { Sessional Papers, No. } 1 \text { (1876) at ii- } \\
182 .\end{array}$ & 0.07 \\
\hline $\begin{array}{l}\text { 1875-76 } \\
\text { (Fiscal Year } \\
\text { Ended } 30 \text { June } \\
\text { 1876) }\end{array}$ & $43,075,840.96$ & $\begin{array}{l}\text { Parliament, "Public Accounts of } \\
\text { Canada, for the Fiscal Year Ended 30th } \\
\text { June, 1876" by R.J. Cartwright in } \\
\text { Sessional Papers, No. } 2 \text { (1877) at xix. }\end{array}$ & $\begin{array}{c}72,025.00 \\
\text { (Note: Treaties } \\
\text { 1-4, Robinson) }\end{array}$ & $\begin{array}{c}\text { Parliament, "Public Accounts of } \\
\text { Canada, for the Fiscal Year Ended 30th } \\
\text { June, 1876" by R.J. Cartwright in } \\
\text { Sessional Papers, No. } 2 \text { (1877) at ii- } \\
187 .\end{array}$ & 0.17 \\
\hline $\begin{array}{c}\text { 1876-77 } \\
\text { (Fiscal Year } \\
\text { Ended } 30 \text { June } \\
\text { 1877) }\end{array}$ & $44,201,619.48$ & $\begin{array}{l}\text { Parliament, "Public Accounts of } \\
\text { Canada, for the Fiscal Year Ended 30th } \\
\text { June, 1877" by R.J. Cartwright in } \\
\text { Sessional Papers, No. } 5 \text { (1878) at xix. }\end{array}$ & $\begin{array}{c}\text { 93,636.00 } \\
\text { (Note: Treaties } \\
\text { 1-5, Robinson) }\end{array}$ & $\begin{array}{c}\text { Parliament, "Public Accounts of } \\
\text { Canada, for the Fiscal Year Ended 30th } \\
\text { June, 1877" by R.J. Cartwright in } \\
\text { Sessional Papers, No. } 5 \text { (1878)) at ii- } \\
178 .\end{array}$ & 0.21 \\
\hline $\begin{array}{l}\text { 1877-78 } \\
\text { (Fiscal Year } \\
\text { Ended } 30 \text { June } \\
\text { 1878) }\end{array}$ & $41,041,919.29$ & $\begin{array}{l}\text { Parliament, "Public Accounts of } \\
\text { Canada, for the Fiscal Year Ended 30th } \\
\text { June, 1878" by S.L. Tilley in Sessional } \\
\text { Papers, No. } 1 \text { (1879) at xix. }\end{array}$ & $\begin{array}{c}138,740.00 \\
\text { (Note: Treaties } \\
1-6, \text { Robinson) }\end{array}$ & $\begin{array}{l}\text { Parliament, "Public Accounts of } \\
\text { Canada, for the Fiscal Year Ended 30th } \\
\text { June, 1878" by S.L. Tilley in Sessional } \\
\text { Papers, No. } 1 \text { (1879) at ii-185 - ii-186. }\end{array}$ & 0.34 \\
\hline $\begin{array}{c}\text { 1878-79 } \\
\text { (Fiscal Year } \\
\text { Ended } 30 \text { June } \\
\text { 1879) }\end{array}$ & $47,456,431.92$ & $\begin{array}{l}\text { Parliament, "Public Accounts of } \\
\text { Canada, for the Fiscal Year Ended 30th } \\
\text { June, 1879" by S.L. Tilley in Sessional } \\
\text { Papers, No. } 2 \text { (1880) at xxiii. }\end{array}$ & $\begin{array}{c}\text { 205,783.43 } \\
\text { (Note: Treaties } \\
\text { 1-7, Robinson) }\end{array}$ & $\begin{array}{l}\text { Parliament, "Public Accounts of } \\
\text { Canada, for the Fiscal Year Ended 30th } \\
\text { June, } 1879 \text { " by S.L. Tilley in Sessional } \\
\text { Papers, No. } 2 \text { (1880) at ii-205. }\end{array}$ & 0.43 \\
\hline $\begin{array}{c}\text { 1879-80 } \\
\text { (Fiscal Year } \\
\text { Ended } 30 \text { June } \\
\text { 1880) }\end{array}$ & $50,879,241.57$ & $\begin{array}{l}\text { Parliament, "Public Accounts of } \\
\text { Canada, for the Fiscal Year Ended 30th } \\
\text { June, } 1880 \text { " by S.L. Tilley in Sessional } \\
\text { Papers, No. } 1 \text { (1881) at xxv. }\end{array}$ & $\begin{array}{c}232,014.02 \\
\text { (Note: Treaties } \\
\text { 1-7, Robinson) }\end{array}$ & $\begin{array}{l}\text { Parliament, "Public Accounts of } \\
\text { Canada, for the Fiscal Year Ended 30th } \\
\text { June, 1880" by S.L. Tilley in Sessional } \\
\text { Papers, No. } 1 \text { (1881) at ii-199. }\end{array}$ & 0.46 \\
\hline $\begin{array}{c}\text { 1880-81 } \\
\text { (Fiscal Year } \\
\text { Ended } 30 \text { June } \\
\text { 1881) }\end{array}$ & $48,223,230.68$ & $\begin{array}{l}\text { Parliament, "Public Accounts of } \\
\text { Canada, for the Fiscal Year Ended 30th } \\
\text { June, 1881" by S.L. Tilley in Sessional } \\
\text { Papers, No. } 2 \text { (1882) at xxv. }\end{array}$ & $\begin{array}{c}\text { 181,107.00 } \\
\text { (Note: Treaties } \\
\text { 1-7, Robinson) }\end{array}$ & $\begin{array}{l}\text { Parliament, "Public Accounts of } \\
\text { Canada, for the Fiscal Year Ended 30th } \\
\text { June, 1881" by S.L. Tilley in Sessional } \\
\text { Papers, No. } 2 \text { (1882) at ii-223. }\end{array}$ & 0.38 \\
\hline $\begin{array}{c}\text { 1881-82 } \\
\text { (Fiscal Year } \\
\text { Ended } 30 \text { June } \\
\text { 1882) }\end{array}$ & $55,794,448.41$ & $\begin{array}{l}\text { Parliament, "Public Accounts of } \\
\text { Canada, for the Fiscal Year Ended 30th } \\
\text { June, 1882" by S.L. Tilley in Sessional } \\
\text { Papers, No. } 1 \text { (1882) at xxiii. }\end{array}$ & $\begin{array}{c}\text { 235,070.00 } \\
\text { (Note: } \\
\text { Annuities, } \\
\text { Robinson) }\end{array}$ & $\begin{array}{l}\text { Parliament, "Public Accounts of } \\
\text { Canada, for the Fiscal Year Ended 30th } \\
\text { June, 1882" by S.L. Tilley in Sessional } \\
\text { Papers, No. } 1 \text { (1882) at ii-229. }\end{array}$ & 0.42 \\
\hline
\end{tabular}




\begin{tabular}{|c|c|c|c|c|c|}
\hline \multirow[t]{2}{*}{ Year } & \multicolumn{2}{|r|}{ Dominion of Canada } & \multicolumn{3}{|c|}{ Indian Affairs } \\
\hline & $\begin{array}{c}\text { Total } \\
\text { Expenditures } \\
\text { (\$) }\end{array}$ & Reference & $\begin{array}{l}\text { Annual Indian } \\
\text { Annuity } \\
\text { Expenditures } \\
\text { (\$) } \\
\end{array}$ & Reference & $\begin{array}{l}\text { \% of Total } \\
\text { Expenditures }\end{array}$ \\
\hline $\begin{array}{l}\text { 1882-83 } \\
\text { (Fiscal Year } \\
\text { Ended } 30 \text { June } \\
\text { 1883) }\end{array}$ & $68,040,463.01$ & $\begin{array}{l}\text { Parliament, "Public Accounts of } \\
\text { Canada, for the Fiscal Year Ended 30th } \\
\text { June, } 1883 \text { " by S.L. Tilley in Sessional } \\
\text { Papers, No. } 2 \text { (1883) at xix. }\end{array}$ & $\begin{array}{l}\text { 194,169.50 } \\
\text { (Note: } \\
\text { Annuities, } \\
\text { Robinson) }\end{array}$ & $\begin{array}{l}\text { Parliament, "Public Accounts of } \\
\text { Canada, for the Fiscal Year Ended 30th } \\
\text { June, } 1883 \text { " by S.L. Tilley in Sessional } \\
\text { Papers, No. } 2 \text { (1883) at ii-227. }\end{array}$ & 0.29 \\
\hline $\begin{array}{l}\text { 1883-84 } \\
\text { (Fiscal Year } \\
\text { Ended } 30 \text { June } \\
1884 \text { ) }\end{array}$ & $87,349,002.83$ & $\begin{array}{l}\text { Parliament, "Public Accounts of } \\
\text { Canada, for the Fiscal Year Ended 30th } \\
\text { June, } 1884 \text { " by S.L. Tilley in Sessional } \\
\text { Papers, No. } 1 \text { (1884) at xix. }\end{array}$ & $\begin{array}{l}\text { 186,429.50 } \\
\text { (Note: } \\
\text { Annuities, } \\
\text { Robinson) }\end{array}$ & $\begin{array}{l}\text { Parliament, "Public Accounts of } \\
\text { Canada, for the Fiscal Year Ended 30th } \\
\text { June, 1884" by S.L. Tilley in Sessional } \\
\text { Papers, No. } 1 \text { (1884) at ii-248. }\end{array}$ & 0.21 \\
\hline $\begin{array}{l}\text { 1884-85 } \\
\text { (Fiscal Year } \\
\text { Ended } 30 \text { June } \\
\text { 1885) }\end{array}$ & $78,621,380.77$ & $\begin{array}{l}\text { Parliament, "Public Accounts for the } \\
\text { Fiscal Year Ended 30th June, 1885" by } \\
\text { A.W. McLelan in Sessional Papers, } \\
\text { No. } 2 \text { (1885) at xxiii. }\end{array}$ & $\begin{array}{c}\text { 185,086.00 } \\
\text { (Note: } \\
\text { Annuities, } \\
\text { Robinson) }\end{array}$ & $\begin{array}{l}\text { Parliament, "Public Accounts for the } \\
\text { Fiscal Year Ended 30th June, 1885” by } \\
\text { A.W. McLelan in Sessional Papers, } \\
\text { No. } 2 \text { (1885) at ii-258. }\end{array}$ & 0.24 \\
\hline $\begin{array}{l}\text { 1885-86 } \\
\text { (Fiscal Year } \\
\text { Ended } 30 \text { June } \\
\text { 1886) }\end{array}$ & $110,631,438.22$ & $\begin{array}{l}\text { Parliament, "Public Accounts for the } \\
\text { Fiscal Year Ended 30th June, 1886" by } \\
\text { A.W. McLelan in Sessional Papers, No. } \\
\qquad 2 \text { (1887) at liv-lix. }\end{array}$ & $\begin{array}{c}\text { 151,506.00 } \\
\text { (Note: } \\
\text { Annuities, } \\
\text { Robinson) }\end{array}$ & $\begin{array}{l}\text { Parliament, "Report of the Auditor- } \\
\text { General on Appropriation Accounts for } \\
\text { the Year Ended 30th June, 1886" by } \\
\text { J.L. McDougall in Sessional Papers, } \\
\text { No. } 3 \text { (1887) at i-72. }\end{array}$ & 0.14 \\
\hline $\begin{array}{l}\text { 1886-87 } \\
\text { (Fiscal Year } \\
\text { Ended } 30 \text { June } \\
\text { 1887) }\end{array}$ & $60,103,630.73$ & $\begin{array}{l}\text { Parliament, "Public Accounts for the } \\
\text { Fiscal Year Ended 30th June, 1887” by } \\
\text { Charles Tupper in Sessional Papers, } \\
\text { No. } 1 \text { (1888) at xxvii. }\end{array}$ & $\begin{array}{l}\text { 140,447.00 } \\
\text { (Note: } \\
\text { Annuities, } \\
\text { Robinson) }\end{array}$ & $\begin{array}{l}\text { Parliament, "Report of the Auditor- } \\
\text { General on Appropriation Accounts for } \\
\text { the Year Ended 30th June, 1887” by } \\
\text { J.L. McDougall in Sessional Papers, } \\
\text { No. } 2 \text { (1888) at i-40. }\end{array}$ & 0.23 \\
\hline $\begin{array}{c}\text { 1887-88 } \\
\text { (Fiscal Year } \\
\text { Ended } 30 \text { June } \\
\text { 1888) }\end{array}$ & $68,027,918.31$ & $\begin{array}{l}\text { Parliament, "Public Accounts for the } \\
\text { Fiscal Year Ended 30th June, 1888” by } \\
\text { George E. Foster in Sessional Papers, } \\
\text { No. } 2 \text { (1888) at xxix. }\end{array}$ & $\begin{array}{c}\text { 137,369.00 } \\
\text { (Note: } \\
\text { Annuities, } \\
\text { Robinson) }\end{array}$ & $\begin{array}{l}\text { Parliament, "Report of the Auditor- } \\
\text { General on Appropriation Accounts for } \\
\text { the Year Ended 30th June, 1888” by } \\
\text { J.L. McDougall in Sessional Papers, } \\
\text { No. } 3 \text { (1889) at B-43. }\end{array}$ & 0.20 \\
\hline $\begin{array}{c}\text { 1888-89 } \\
\text { (Fiscal Year } \\
\text { Ended } 30 \text { June } \\
\text { 1889) }\end{array}$ & $71,147,964.27$ & $\begin{array}{l}\text { Parliament, "Public Accounts for the } \\
\text { Fiscal Year Ended 30th June, 1889” by } \\
\text { George E. Foster in Sessional Papers, } \\
\text { No. } 3 \text { (1889) at xxvii. }\end{array}$ & $\begin{array}{l}\text { 141,401.00 } \\
\text { (Note: } \\
\text { Annuities, } \\
\text { Robinson) }\end{array}$ & $\begin{array}{l}\text { Parliament, "Report of the Auditor- } \\
\text { General on Appropriation Accounts for } \\
\text { the Year Ended 30th June, 1889" by } \\
\text { J.L. McDougall in Sessional Papers, } \\
\text { No. } 5 \text { (1890) at B-40 - B-41. }\end{array}$ & 0.20 \\
\hline $\begin{array}{c}\text { 1889-90 } \\
\text { (Fiscal Year } \\
\text { Ended } 30 \text { June } \\
\text { 1890) }\end{array}$ & $62,781,366.16$ & $\begin{array}{l}\text { Parliament, "Public Accounts for the } \\
\text { Fiscal Year Ended 30th June, 1890" by } \\
\text { George E. Foster in Sessional Papers, } \\
\text { No. } 1 \text { (1891) at xxvii. }\end{array}$ & $\begin{array}{l}\text { 145,215.00 } \\
\text { (Note: } \\
\text { Annuities, } \\
\text { Robinson) }\end{array}$ & $\begin{array}{l}\text { Parliament, "Report of the Auditor- } \\
\text { General on Appropriation Accounts for } \\
\text { the Year Ended 30th June, 1890" by } \\
\text { J.L. McDougall in Sessional Papers, } \\
\text { No. } 3 \text { (1891) at A-67. }\end{array}$ & 0.23 \\
\hline $\begin{array}{c}\text { 1890-91 } \\
\text { (Fiscal Year } \\
\text { Ended } 30 \text { June } \\
\text { 1891) }\end{array}$ & $57,913,259.62$ & $\begin{array}{l}\text { Parliament, "Public Accounts for the } \\
\text { Fiscal Year Ended 30th June 1891” by } \\
\text { George E. Foster in Sessional Papers, } \\
\text { No. } 2 \text { (1891) at xxvii. }\end{array}$ & $\begin{array}{l}\text { 142,806.00 } \\
\text { (Note: } \\
\text { Annuities, } \\
\text { Robinson) }\end{array}$ & $\begin{array}{l}\text { Parliament, "Report of the Auditor } \\
\text { General for the Year Ended 30th June, } \\
\text { 1891" by J.L. McDougall in Sessional } \\
\text { Papers, No. } 1 \text { (1892) at A-76. }\end{array}$ & 0.25 \\
\hline
\end{tabular}




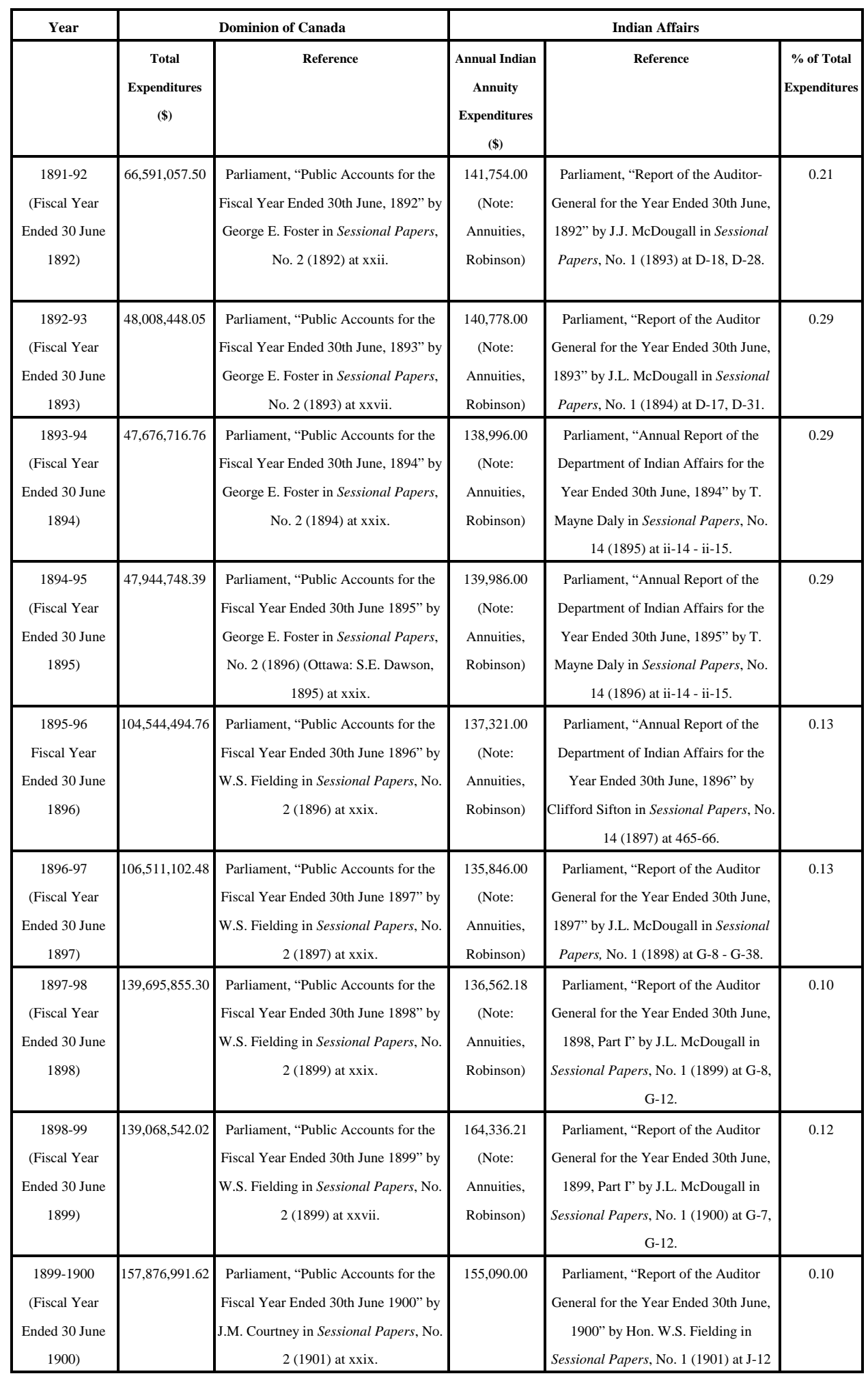

